\title{
EVALUATING AND ADMITTING EXPERT OPINION TESTIMONY IN CHILD SEXUAL ABUSE PROSECUTIONS
}

\author{
DiANa YounTs
}

\section{INTRODUCTION}

Recent research shows that much of the expert evidence offered by prosecutors in child sexual abuse trials is unreliable. ${ }^{1}$ The issue of the reliability of expert evidence in child sexual abuse trials lias already reached the Supreine Court, which in Idaho v. Wright ${ }^{2}$ inandated that courts develop criteria of reliability to test expert evidence before admitting it in child sexual abuse trials when a defendant's Sixth Amendment confrontation right is implicated. This Note provides courts guidelines for assessing the validity of an abuse investigation to determine when expert evidence from an investigative interview should be adımissible.

Legal concerns about the reliability of expert evidence in child sexual abuse cases stein from the debate within the scientific world. Social scientists are engaged im a highly polarized debate about how child sexual abuse allegations should be investigated. On one side are child advocates $^{3}$ who care passionately about helping sexually abused children reveal their experiences to imvestigative authorities. On the other side are mental health professionals and social science researchers who care passionately that inappropriate imvestigative techniques and bad science have labeled unabused children as abused and have led to false accusations and prosecutions. As one commentator has stated: "No problem in child and adolescent psychiatry stirs up more heated discussion than

\section{See infra Part III.}

2. 110 S. Ct. 3139 (1990); see also Maryland v. Craig, 110 S. Ct. 3157 (1990). In Craig, Justice Scalia argued in an impassioned dissent that courts should be particularly insistent in protecting innocent defendants from false child sexual abuse allegations and discussed at length the reliability problems created by children's suggestibility in child sexual abuse prosecutions. Justice Scalia, joined by Justices Brennan, Stevens, and Marshall, was dissenting to the majority holding that a defendant's Sixth Amendment confrontation right can be overridden by societal interests in protecting abused children from further trauma. See id. at 3175-76 (Scalia, J., dissenting).

3. For the purposes of this Note, the term "child advocate" refers to any person who testifies exclusively for the prosecution or who consistently takes a prosecution-oriented viewpoint when writing or discussing child sexual abuse. 
does child sexual abuse. . . [O]ur ennotions are racing well ahead of our research projects." 4

The debate has far-ranging implications for the legal system. It raises the specter that unrehable evidence is routinely adinitted in child sexual abuse prosecutions and that innocent defendants face prosecution and conviction because of unrehable expert testimony. Legal professionals and the justice system need to be aware of the research and ideology that lie behind this debate so that they can best adopt a method for reaching just outcoines in abuse cases.

Because child sexual abuse investigations are often poorly conducted and child sexual abuse is overdiagnosed, ${ }^{5}$ courts need to take an active role in determining the reliability of expert testimony before adinitting it into evidence. Careful review of the social science hiterature indicates that children are susceptible to suggestive interviewing techniques and that such techinques can render children's accounts of abuse unreliable. ${ }^{6}$ A number of studies have shown that children will he when they have a inotivation to he, ${ }^{7}$ that they are susceptible to accommodating their reports of events to fit what they perceive the adult questioner to believe, ${ }^{8}$ and that inappropriate post-event questioning can actually change a child's cognitive inemory of an event. ${ }^{9}$ Even the studies that concluded that children are resistant to suggestion found a small percentage of children who were not. ${ }^{10}$

The social science hiterature also raises grave concerns that the use of anatomically detailed dolls ${ }^{11}$ during investigative interviews can lead interviewers to behieve that abuse has occurred when in fact it has not. For instance, in one study in which the abuse evaluator was blind to the abuse status of the children, the evaluator had a sixty-seven percent false-

4. Lenore C. Terr, Child Sexual Abuse: Why the Controversy?, 28 J. AM. ACAD. CHILD \& ADOLESCENT PSYCHLATRY 788, 788 (1989).

5. See, e.g., Kathleen M. Quinn et al., Resolved: Child Sex Abuse Is Overdiagnosed, 28 J. AM. ACAD. Child \& ADOLESCENT PsYCHiATRY 789, 789 (1989) (stating that "inadequate investigations lead to an overdiagnosis of child sexual abuse") (debate among four professionals, Kathleen Quinn, Diane Schetky, Lucy Berliner, and Maria Sauzier).

6. See infra Part III.

7. See infra Part III(B) (1).

8. See infra Part III(B)(2).

9. See infra Part III(B)(4).

10. See infra Part III(B)(3).

11. See infra Part III(A). Anatomically detailed dolls are commonly used in child sexual abuse investigations. As the name suggests, these dolls have gemitals. Some people believe that the use of these dolls in interviews aids children's abilities to recount sexually abusive events. 
positive rate (sixty-seven percent of those she said were abused were not abused). ${ }^{12}$

Because of the serious implications of the controversy surrounding child sexual abuse trials, courts do a disservice to children and to defendants if they allow "a battle of the experts" in the courtrooin instead of making preliminary determinations of the evidence's reliability. Not only are many defendants unable to afford experts, but much of the harm is done before trial-both to the falsely accused defendant and to any child who lias been falsely labeled as abused.

Part I discusses tlie inajor criticisms levied at tlie liandling of abuse investigations and the danger of courts naively assuming that young children are incapable of false accusations of sexual abuse. Part II discusses evidentiary and constitutional issues associated with child sexual abuse trials, sucli as the admissibility of an expert's testimony concerning information gained from an abuse investigation. Part II focuses on Idaho v. Wright, ${ }^{13}$ the Supreme Court decision that gives courts guidelines to follow when admitting liearsay testimony under the Confrontation Clause. Part III discusses recent social science studies tliat have evaluated the reliability of using anatomically detailed dolls to determine whether child sexual abuse has occurred, investigated children's suggestibility, and examined the incidencc-rate of false allegations of child sexual abuse. Part III also addresses the common probleins of abuse investigations-probleıns of suggestivity, interviewer bias, and pursuit of an agenda. Part IV discusses low the research findings of Part III affect the evaluation process that courts must undertake before admitting expert opimion testimony ${ }^{14}$ in child sexual abuse prosecutions. Part IV also gives courts guidelines to follow in determining whether the investigation was conducted properly.

\section{Why Child Sexual Abuse Investigations Abe Under Frre}

Child sexual abuse was once a largely ignored and unrecognized crime. ${ }^{15}$ Since the 1970 s, lowever, there has been a growing awareness of child sexual abuse and reports of it have skyrocketed. In 1976, a total

12. George M. Realmuto et al., Specificity and Sensitivity of Sexually Anatomically Correct Dolls in Substantiating Abuse: A Pilot Study, 29 J. AM. ACAD. CHILd \& Adolescent PsychIATRY 743, 745 (1990); see also infra Part III(A).

13. 110 S. Ct. 3139 (1990).

14. This Note does not attempt to give guidelines for syndrome evidence, social framework evidence, or for medical evidence of physical sexual abuse.

15. See Douglas J. Besharov, Unfounded Allegations-A New Child Abuse Problem, PuB. INTEREST, Spring 1986, at 18, 19 ("[C]hild maltreatment was a social problem largely hidden from public view. Few abused or neglected children were reported to the authorities.") (author is the founding director of the National Center on Child Abuse and Neglect (NCCAN)). 
of 7559 reports of sexual abuse were made to reporting agencies. In 1986, the last year for which comprehensive national figures are available, that number had increased to $200,000 .{ }^{16}$ Since 1986, agencies have reported an ever-mcreasing number of mcidents. ${ }^{17}$ Prosecutions for child sexual abuse have imcreased concurrently with the number of reports. ${ }^{18}$ Traditionally, child sexual abuse was seen as best handled by the family and juvenile courts. ${ }^{19}$ Today, an allegation of child sexual abuse is viewed as a matter for the criminal courts. ${ }^{20}$ Many reforms have been instituted to improve the prosecutability of child sex abuse cases. These reforms have included admitting psychological expert testimony, providing interdisciplinary teams to imvestigate allegations of abuse, establishmg special child abuse prosecution unts, assigning the same prosecutor to all stages of a case, abolishing corroboration requirements, and extending statutes of limitations. ${ }^{21}$

Typically, abuse evaluators ${ }^{22}$ act as the investigative arm of the prosecutor's office. Decisions to prosecute are partly based on an evaluator's determination that the child has been abused. ${ }^{23}$ Even though prosecutors rely on the evaluations made by social workers, the legal world has paid surprisimgly httle attention to the way these social workers handle their investigations. In the scientific world, researchers have criticized both the qualifications of the social workers and the validity of their investigative techiriques. For instance, Kathleen M. Quinn, a child psychiatrist at Case Western Reserve University, has found that "improper investigatory techuriques are leading to premature and incorrect

16. L.B. Suski, Child Sexual Abuse: An Increasingly Important Part of Child Protective Service Practice, 3 Protecting Children 3 (1986).

17. See National Committee for Prevention of Child Abuse, Current Trends 1 N Child Abuse Reporting and Fataltties: The Results of the 1989 AnNual FifTy State SURVEY (1990), reported in Examining Proposed Legislation to Authorize Funds for Certain Child Abuse and Neglect Provisions: Hearings Before the Subcomm. on Children, Family, Drugs, and Alcoholism of the Sen. Comm. on Labor and Human Resources, 101st Cong., 2d Sess. 71, 77 (1990) (stating that in 1989, 2,400,000 cases of child abuse were reported nationally and that $16 \%(386,400)$ of those reports involved child sexual abuse).

18. See, eg., Douglas J. Besharov, Protecting the Innocent: the McMartin Preschool Case, NAT'L ReV., Feb. 19, 1990, at 44, 44.

19. See Josephine A. Bulkley, The Impact of New Child Witness Research on Sexual Abuse Prosecutions, in PERSPectives on ChILdREN's Testimony 208, 209 (Stephen J. Ceci et al. eds., 1989).

20. See id.

21. Id. at 210; see also infra note 245.

22. Abuse evaluators, who are often social workers, work for a variety of agencies (including the Department of Social Services) or for quasi-independent child protection teams.

23. See Donald C. Bross et al., The New Child Protection Team Handbook 391-94 (1988). 
assessments of the child's experiences and to overdiagnosis of child sexual abuse."24 She pinpoints the major problems facing professionals as "lack of professional resources and training, lack of investigatory independence, improper interviewer techniques and behaviors, inadequate data bases, contamination of cases by external influences, and failure to understand the nature of false allegations." 25 The errors Dr. Quinn mentions translate into evidentiary unrehability when "experts" base their testimony on interviews plagued with these problems.

Courts should take seriously the accusations that those agencies charged with the responsibility of mvestigating abuse charges often do a poor job. ${ }^{26}$ In some cases a diagnosis of sexual abuse is made even when the child has said nothing at all about being abused. In one publicized case in Hermepin County, Minnesota, a psychotherapist's diagnosis of sexual abuse was based solely on one child's spontaneous adamant denial that her father had molested her. She stated, "[s]uch an exphicit and emphatic denial is atypical in a 4-year-old, even a precocious one" and concluded that the child must have been abused. ${ }^{27}$ In another case, a social worker determined that the child had been sexually abused after a one-hour interrogation in which the child failed to recount any sexual abuse and there were no physical signs of abuse. The social worker decided that the child was suffering from Child Sexual Abuse Accommodation Syndrone (CSAAS) and was being secretive about the abuse. ${ }^{28}$

24. Quinn et al., supra note 5, at 789.

25. Id.; see also id. at 791 (statement of Dr. Diane Schetky, a psychiatrist who has testified in criminal, family, and juvenile court proceedings):

[M]any clinicians continue to make a hasty or ill-considered diagnosis of child abuse.

Common errors include bias and failure to obtain both parental sides of the story, failure to consider what else is going on in the child's life, failure to inquire about prior sexual abuse in the child or parents' lives, misinterpretation of medical findings, inadequate tine spent with the child or too many prolonged interrogations of the child, the use of biased, either/ or coercive or age imappropriate questions, techniques that introduce leadimg or educational materials, differential reinforcement of responses, and selective interpretation of the child's behavior. . . . It is my contention, based on numerous case reviews, that some clinicians are performing madequate evaluatious. These inadequate investigations lead to an overdiagnosis of child sexual abuse, particularly where young children are involved.

26. See id. at 791; see also HOLLIDA WAKEFIELD \& RALPH UNDERWAGER, ACCUSATIONS OF Child Sexual Abuse 19-47 (1988); David C. Raskin \& John C. Yuille, Problems in Evaluating Interviews of Children in Sexual Abuse Cases, in Perspectives on Children's Testimony, supra note 19 , at $184,204$.

27. Elissa P. Benedek \& Diana H. Schetky, Problems in Validating Allegations of Sexual Abuse, Part 2: Clinical Evaluation, 26 J. AM. ACAD. Child \& AdOlesCent PsYChiATRY 916, 918 (1987).

28. Evaluation performed by Duke Child Protection Team on July 17, 1989. Based on this evaluation, criminal charges were filed, but dropped 16 months later. Dr. Roland Summit first coined the term "Child Sexual Abuse Accommodation Syndrome." He identified the "syndrome" as consisting of five behavioral characteristics: secrecy; helplessness; entrapment and accommodation; delayed, conflicted, and unconvincing disclosure; and retraction. See Roland C. Summit, The Child Sexual Abuse Accommodation Syndrome, 7 CHILD ABUSE \& NEGLECT 177 (1983); see also Robert J. Levy, Using "Scientific" Testimony to Prove Child Sexual Abuse, 23 FAM. L.Q. 383 (1989). Levy 
Idaho v. Wright ${ }^{29}$ provides an example of an abuse allegation that surfaced only after the child had been questioned by a professional (in this case, a pediatrician). ${ }^{30}$ The original statement about sexual abuse had come from Wright's older daughter who said that the younger child had been abused. The pediatrician interviewed the younger child after she had been taken from her home and had spent the previous night in police custody. After being asked a series of highly leading questions, the child's only statements about abuse was one "yes" answer and an ambiguous statement concerning abuse. At trial, the pediatrician stated that "[s] he wonld not elucidate ... what kind of touching was taking place, or how it was happening." 31 This is obviously not a situation im which a child has spontaneously told a story of having been abused. Therefore, the trial court made a grave error $m$ admitting the testimiony without first determining if the pediatrician conducted the interview in a way that was not undnly suggestive. Because of that error, the Supreme Court overruled the trial verdict. ${ }^{32}$

Furthermore, courts have often naively admitted testimony based on abuse investigations. When admitting a pediatrician's testimiony about a child's out-of-court statements, one court stated that " '[t]he nature of the stateinents ... fall outside the general behevability that a child could ... or would make them up. This is simply not the type of statement ... that one would expect a child to fabricate." "33 This court's attitude is based on common sense-it seems logical that a child would not make up

provides a succinct criticism of using CSAAS in courtroom testinnony. He points out that Summit formulated the diagnostic description in a paper whose purpose was not to provide a sexual abuse test, but to improve therapy and advocacy for children. Summit reported his clinical findings but did not provide data in the article that showed how he had made the determination that CSAAS exists. He did not provide any information from which an informed judgment can be inade as to whether symptoms of the "syndrome" might be validly considered determinative or even corroborative of sexual abuse. He also failed to disclose whether children's developmental levels affect how the syndroine is manifested. See id. at 392 . In addition, because the syndrome has not been researched enough to qualify as a valid phenomenon, it is not listed in the American Psychiatrists Association's Diagnostic and Statistical Manual of Mental Disorders(DSM-IIIR) (APA ed., rev. 3d ed. 1987), the diagnostic bible for clinicians. Even assuming that the syndrome is valid, many of the identifying features of the syndrome could be exhibited by a child who has not been abused. For example, a child who is being secretive about the abuse and refuses to reveal it would be indistinguishable from a child who has not been abused. Furthermore, Summit identified all the children in his sample as being the victims of incest. Behavioral characteristics of incest victims cannot necessarily be generalized to behavior characteristics of victims of extra-familial abuse. Victims of extrafamilial abuse likely facc less intra-familial pressure to keep the abuse secret or to recant once they do revcal the abuse, and probably have fewer conflicting emotions when revealing the abuse.

29. 110 S. Ct. 3139 (1990).

30. For a synopsis of the pertinent facts of the case, see infra note 49 .

31. Wright, $110 \mathrm{~S}$. Ct. at 3144.

32. See id. at $\mathbf{3 1 4 5 .}$

33. State v. Giles, 772 P.2d 191, 194-95 (Idaho 1989) (quoting unpublished trial transcript). 
a story about being sexually abused. In reality, however, children can be influenced by adults to produce false allegations-either through an adult's misinterpretation of what a child has said, hysteria about the possibility of abuse, or through maliciousness on the part of the adult. ${ }^{34}$ Some of the studies examining children's suggestibility have found children to be prone to conforming their stories to the behiefs of the questioning adult. ${ }^{35}$ In addition, in legitimate cases of abuse, children soinetimes name a person other than the true perpetrator. ${ }^{36}$. Furthermore, as Drs. Benedek and Schetky have pointed out, "[a]s there is more media coverage of sexual abuse, parents and the professional community are more likely to suspect sexual abuse as a cause for symptom formation, even when sexual abuse has not occurred."37 It is highly important, then, to look at the circunistances from which the original allegation sprang to determine whether a child spontaneously reported being abused, or whether the abuse allegation came after adult questioning.

\section{EVIDENTIARY AND CONSTITUTIONAL CONCERNS OF EXPERT TESTIMONY}

The evidentiary prob]ems surrounding child sexual abuse cases stein from the central role that expert witnesses play in child sexual abuse trials. This Part explaims the special rehability concerns associated with expert witnesses in child sexual abuse trials and discusses the evidentiary and constitutional issues that pertain to a court's decision to admit expert testimony about child sexual abuse.

34. See Jeffry H. Gallett, Judicial Management of Child Sexual Abuse Cases, 23 FAM. L.Q. 477, 482 (1989) (author is a judge of the Family Court of the State of New York) (noting that some of the sexual abuse allegations in the author's courtroom are manufactured by the parents and the child or that in some cases the problem is not that children or parents are lying but that the facts are misconstrued); see also Daniel C. Schuman, False Accusations of Physical and Sexual Abuse, 14 BuLL. AM. ACAD. PSYChIATRY \& L. 5 (1986) (giving case descriptions of family dynamics where abuse was wrongly alleged); Alayne Yates \& Tim Musty, Preschool Children's Erroneous Allegations of Sexual Molestation, 145 AM. J. Psychiatry 989 (1988) (giving case descriptions of children who falsely alleged that they had been abused).

35. See, e.g., Alison Clarke-Stewart et al., Manipulating Children's Interpretations Through Interrogation (paper presented at the Biennial Meeting of the Society for Research on Child Development, May 2, 1989), reported in Gail S. Goodman \& Alison Clarke-Stewart, Suggestibility in Children's Testimony: Implications for Sexual Abuse Prosecutions, in THE SUgGestiBILITY of CHILDREN'S RECOLLECTIONS: IMPLICATIONS FOR EYEWITNESS TESTIMONY 99 (John Doris ed., 1991) [hereinafter Suggestibility of ChILdREn's Recollections]; see also Stepheu J. Ceci, Age Differences in Suggestibility: Narrowing the Uncertainties, in CHILDREN's EYEwTrNEsS MEMORY 79, 82 (Stephen J. Ceci et al. eds., 1987) [hereinafter Ceci, Age Differences].

36. David P.H. Jones \& J. Melbourne McGraw, Reliable and Fictitious Accounts of Sexual Abuse to Children, 2 J. INTERPERSONAL VIOLENCE 27 (1987).

37. Benedek \& Schetky, supra note 27 , at 917. 
The outcome of child sexual abuse trials often turns on the credibility of the examining expert who testifies to her conclusions about the child's abuse status and to the child's out-of-court hearsay statements and actions. In these trials, especially those that imvolve young children, expert witnesses are often the primary evidentiary vehicle for presenting the prosecution's case. If the child does not testify, as frequently occurs in sexual abuse cases involving young children, the expert may be the only witness to testify to the child's out-of-court hearsay allegations. ${ }^{38}$ Additionally, there is often hittle or no corroborating evidence to support a child's allegations. ${ }^{39}$ It is therefore critical to the truth-seeking function of a trial that the expert's testimony be rehable.

Even when the child does testify, the expert is still essential to the court's truthfinding role. Not only does the expert serve to corroborate the child's testimony, but she can also be used by the prosecution to testify to a spectrum of issues-imcluding offering an opimion as to whether the child was sexually abused, the truthfulness of the child, the truthfulness of children in general when alleging sexual abuse, the identity of the abuser, and the child's statements to the evaluator during the investigative interview. 40 In many cases, courts must grapple with complex evidentiary issues when determining the admissibility of testinony because the child's hearsay statements do not fall neatly into estabhished hearsay exceptions. To cope with these problems, many states have created special child hearsay exceptions, ${ }^{41}$ or have expansively interpreted

38. In many jurisdictions, the medical exception to hearsay evidence rules has been expanded to encompass such statements. See Robert P. Mosteller, Child Sexual Abuse and Statements for the Purpose of Medical Diagnosis or Treatment, 67 N.C. L. REv. 257, 257 (1989). Children's statements to other individuals are usually difficult to fit into traditional hearsay exceptions. See generally Michael H. Graham, The Confrontation Clause, the Hearsay Rule, and Child Sexual Abuse Prosecutions: The State of the Relationship, 72 MinN. L. REv. 523 (1988).

39. Bulkley, supra note 19, at 209-10.

40. See Veronica Serrato, Note, Expert Testimony in Child Sexual Abuse Prosecutions: A Spectrum of Uses, 68 B.U. L. REv. 155 (1988) (delineating areas in which expert testiniony has been allowed); see also State v. Wise, 390 S.E.2d 142 (N.C. 1990) (holding that although expert testimony is not admissible on the credibility of a witness, it was admissible for the expert to testify that the child was "genuine"); Dirk Lorenzen, Comment, The Admissibility of Expert Psychological Testimony in Cases Involving the Sexual Misuse of a Child, 42. U. MIAMI L. REv. 1033, 1068-71 (1988) (suggesting that experts act to elicit and preserve the testimony of children to compensate for children's cognitive limitations on their abilities to testify competently).

41. At least 20 states have adopted special child hearsay exceptions. See Graham, supra note 38, at 534 (summarizing each state's statutory hearsay exception). For example, Arizona's child hearsay exception statute provides:

[A] statement made by a minor who is under the age of ten years describing any sexual offense or physical abuse performed with, on or witnessed by the minor, which is not otherwise admissible by statute or court rule, is admissible in evidence in any criminal or civil proceeding if both of the following are true:

1. The court finds, in an in camera hearing, that the time, content and circumstances of the statement provide sufficient imdicia of reliability. 
Under the Sixth Amendment Confrontation Clause, a defendant has the right to confront his accuser. ${ }^{45}$ Although the Supreme Court has declined to interpret the Clause to provide an absolute right of the defendant to face his accuser, ${ }^{46}$ it has required that the out-of-court statements contain "particularized guarantees of trustworthiness" 47 if they do not fall within a firmly rooted hearsay exception.

The Idaho v. Wright ${ }^{48}$ decision specifically addressed trustworthiness problems and admissibility when a child abuse investigator testifies to a child's hearsay statements. Because the child did not testify at trial, the defendant challenged the expert's hearsay testimony about the child's allegations as violative of his right to confront his accuser. Under the facts in the case, ${ }^{49}$ the Supreme Court held that the admission of the

45. U.S. ConsT. amend. VI.

46. See, e.g., Maryland v. Craig, 110 S. Ct. 3157, 3170 (1990) (holding that "although face-toface confrontation is not an absolute constitutional requirement, it may be abridged only where there is a 'case-specific finding of necessity' ") (citation omitted). See also White v. Illinois, 60 U.S.L.W. 4094, 4095 (U.S. Jan. 15, 1992) (holding that the Confrontation Clause permits admission of hearsay testimony without a showing that the declarant is unavailable).

47. Ohio v. Roberts, 448 U.S. 56,66 (1980).

48. 110 S. Ct. 3139 (1990).

49. In Wright, Laura Wright and her boyfriend Robert Giles were charged and convicted of lewd conduct with Wright's two daughters, who were five and two years old, respectively, at the time of the alleged abuse. (The older daughter was from a previous marriage and Giles was the father of the younger daughter.) The allegation surfaced when the older daughter allegedly told her father's girlfriend (Cynthia Goodman) that Giles had had sexual intercoursc with her while Wright held her down and that she had seen Giles and Wright do the same thing with her younger sister. Goodman reported these disclosures to the police the next day and took the older daughter to the hospital where she was examined by Dr. Jambura, a pediatrician. Police and welfare officials took the younger daughter, Kathy, into custody that day. Dr. Jambura examined and interviewed her the following day. Id. at 3143 . The following testimony was held inadmissible:

A. [by Dr. Jambura] ... I ... proceeded to just gently start asking questions about, 'Well, how are things at home, you know, those sorts. Gently moving into the dounestic situation und then moved into four questions in particular, as I reflected in my records, "Do you play with daddy? Does daddy play with you? Does daddy touch you with his pee-pee? Do you touch his pee-pee?' And agam we then established what was meant by pec-pee, it was a generic term for genital area.

Q. [by the prosecutor] Before you get into that, what was, as best you recolleet, what was her respouse to the question 'Do you play with daddy?'

A. Yes, we play - I remember her making a comment about yes we play a lot and expanding on that and talking about spending time with daddy.

Q. And 'Does daddy play with you?' Was there any response?

A. She responded to that as well, that they played together in a variety of circumstances and, you know, seemed very unaffected by the question.

Q. And then what did you say and her response?

A. When I asked her 'Does daddy touch you with his pee-pec,' she did admit to that. When I asked, 'Do you touch his pee-pee,' she did not have any response.

Q. Did you notice any change in her affect or attitude in that line of questioning?

A. Yes.

Q. What did you observe?

A. She would not-oh, she did not talk any further about that. She would not elucidate what exactly - what kind of touching was taking place, or how it was happening. She did, however, say that daddy does do this with me, but he does it a lot more with my sister than with nie. 
traditional hearsay exceptions (such as the medical exception) ${ }^{42}$ to accommodate children's statements that would otherwise not be admissible. In addition, children's hearsay statements may come in under a general catchall exception, ${ }^{43}$ or when the imvestigator testifies to the underlying basis of her opinion. ${ }^{44}$

\section{A. Idaho v. Wright: Child Sexual Abuse, Hearsay, and the Confrontation Clause}

The evidentiary issues associated with child sexual abuse cases take on a constitutional dimension when the child does not testify at trial.

2. Either of the following is true:

(a) The minor testifies at the proceedings.

(b) The minor is unavailable as a witness, provided that if the minor is unavailable as a witness, the statement may be admitted only if there is corroborative evidence of the statement.

ARIZ. REv. STAT. ANN. § 13-416 (1989). Similarly, the California Evidence Code provides:

[A] court, in its discretion, may determine that a stateinent of the complaining witness is not made inadmissible by the hearsay rule if it finds all of the following:

(a) The statement was made by a minor child under the age of 12 , and the contents of the statement were included in a written report of a law enforcement official or an employee of a county welfare departinent.

(b) The statement describes the minor child as a victim of sexual abuse. . .

(e) The minor child is found to be unavailable ... or refuses to testify.

Cal. Evid. Code $\$ 1228$ (West Supp. 1991).

42. See FED. R. EvID. 803(4) (excepting from the prohibition against admission of hearsay "[s]tatements made for purposes of medical diagnosis or treatment and describing medical history, or past or present symptoms, pain, or sensations, or the inception or general character of the cause or external source thereof insofar as reasonably pertinent to diagnosis or treatment"). State evidence codes often elosely track the Federal Rules of Evidence. Many states have adopted the federal rules either without inodification, or with some modification. See EDWARD W. ClEARY ET AL., MCCoRMICK ON EVIDENCE vii (3d ed. 1984) (noting that the federal rules have been adopted in over half the states "largely without change of substance"). See, e.g., ILL. ANN. STAT. ch. 38, para. 115-13 (Smith-Hurd 1990):

In a prosecution for violation of [sexual assault statutes] stateinents made by the victim to medical personnel for purposes of inedical diagnosis or trcatment including descriptions of the cause of symptom, pain or sensations, or the inception or general character of the cause or external source thereof insofar as reasonably pertinent to diagnosis or treatment shall be admitted as an exception to the hearsay rule.

See also State v. Nelson, 406 N.W.2d 385 (Wis. 1987):

[W] do not believe that, because a child is only three or four years of age at the time he or she goes to a doctor, the child is unable to comprehend that the child is involved in the process of receiving diagnosis or treatment. ... Just as a child three or four years of age understands that statements made to a physician will be used by that physician to ease the physical pain of the child, we conclude that such a child also understands that statements made to a psychologist will be used by the psychologist to ease the emotional or psychologId. at 391 . ical injuries of the child.

43. See FED. R. EVID. 803(24) (admitting "[a] statement not specifically covered by any of the foregoing exceptions but having equivalent circumstantial gnarantees of trustworthiness"); IDAHO R. Evid. 803(24) (same language).

44. See FED. R. EvID. 705 ("The expert may testify in terms of opinion or inference and give reasons therefor without prior disclosure of the underlying facts or data, unless the court requires otherwise. The expert may in any event be required to disclose the underlying facts or data on crossexamination."); IDAHo R. EvID. 705 (substantially the same). 
child's hearsay statements to a pediatrician violated the defendant's Confrontation Clause rights because the totality of the circumstances did not mdicate that the child's statements contamed " 'particularized guarantees of trustworthiness." "50 The Court stated that if the statements had fallen under a firmly rooted hearsay exception there would be no need for further imquiry into their rehability. ${ }^{51}$ Idaho $v$. Wright thus created an affirmative duty for courts to evaluate whether an expert's testimony to a child's hearsay statements contain "particularized guarantees of trustworthiness" before adıntting the testimony imto evidence whenever a defendant's Sixth Amendment confrontation right is at issue.

The reasoning in Idaho v. Wright is not limited to cases in which the child does not testify at trial. The Wright Court was concerned with the rehability of expert testimony im any context. The Court acknowledged that "hearsay rules and the Confrontation Clause are generally designed to protect similar values" 52 and that "hearsay statements [that] do not fall within a firmly rooted hearsay exception ... are presumptively unrehable."53 Therefore, the Wright Court's mandate that trial courts must look for imdicia of rehiability is applicable whenever an expert testifies to a child's hearsay statements, whether or not the child testifies.

This conclusion is also supported by the Supreme Court's holding in Ohio v. Roberts, ${ }^{54}$ another case involving a Confrontation Clause challenge to hearsay testimony. In Roberts, the Court held that the prosecution must produce or demonstrate the unavailability of the witness and the witness's hearsay statements must bear "adequate 'imdicia of rehability." "ss The Court further stated that "[r] ehability can be imferred without inore $\mathrm{m}$ a case where the evidence falls within a firmly rooted hearsay exception. In other cases, the evidence must be excluded, at least absent a showing of particularized guarantees of trustworthiness." 56

Q. And how did she offer that last statenent? Was that in response to a question or was that just a volunteered statement?

A. That was a volunteered stateinent as I sat and waited for her to respond, again after she sort of clammed-up, and that was the next statement that she inade after just allowing some silence to occur.

Id. at 3143-44.

50. Id. at 3146 (quoting Roberts, 448 U.S. at 66). The Court considered the need for "particularized guarantees of trustworthiness" because the child's statements were admitted under Idaho's residual hearsay exception, IDAHo R. Evid. 803(24). For Idaho's residual hearsay exception, see supra note 43.

51. See Wright, $110 \mathrm{~S}$. Ct. at 3149.

52. Id. at 3146 (quoting California v. Green, 399 U.S. 149, 155 (1970)).

53. Id. at 3148 (quotation omitted).

54. 448 U.S. 56 (1980).

55. Id. at 66 .

56. Id. The Court did not provide a precise definition of "firntly rooted" nor did it set out any guidelines for determining when an exception is "firmly rooted." It merely stated that "certain hearsay exceptions rest upon such solid foundations that admission of virtually any evidence within 
In White v. Illinois, ${ }^{57}$ the Court clarified its holding in Roberts, and held that the Confrontation Clause is satisfied when the "proffered hearsay has sufficient guarantees of reliability to coine within in a firmly rooted exception to the hearsay rule."58 The White opinion thus eliminated the requirement that the prosecution must either produce the declarant at trial or the trial court must find the declarant is unavailable. ${ }^{59}$

Therefore, under both White and Roberts, hearsay that is not adınissible for Confrontation Clause purposes would also not be admissible as hearsay, whether or not the child testifies in court. That is, it is virtually inipossible for an out-of-court statement that does not bear indicia of rehiability when the Confrontation Clause is iniplicated to overcome its "presumptive unrehiability" as hearsay. Despite the Roberts holding, some courts have declined to require "indicia of rehability" in the hearsay statements unless the defendant has raised his Sixth Amendinent confrontation right as an issue. ${ }^{60}$ This seems to be the wrong result. The Supreme Court in Roberts, Wright, and White merely dechined to constitutionalize evidentiary rules; 61 it did not say that evidentiary rules and rehiability concerns can be iguored unless a defendant's constitutional rights are at issue.

The Supreine Court in Idaho v. Wright acknowledged that "hearsay rules and the Confrontation Clause are generally desigued to protect sinilar values,"62 and that they " "stem from the same roots." "63 Most recently, in White, an opmion written by Chief Justice Relinquist, the

them comports with the 'substance of the constitutional protection." "Id. (quoting Mattox v. United States, 156 U.S. 237, 244 (1895)).

57. 60 U.S.L.W. 4094 (U.S. Jan. 15, 1992).

58. Id. at 4097.

59. Id. at 4095 .

60. See, e.g., State v. Wright, 775 P.2d 1224 (Idaho 1989); State v. Giles, 772 P.2d 191 (Idaho 1989). These two decisions by the Idaho Supreme Court illustrate this point. Giles and Wright were codefendants who were tried and convicted withm the same trial. Wright, 775 P.2d at 1225 . The defendants filed separate appeals, both raising on the issue of the pediatrician's testimony concerning the child's hearsay statements. Id. Giles's appeal failed to frame the issue as violating the Confrontation Clause. Id. The Idaho Supreme Court affirmed Giles's conviction, but reversed Wright's conviction. Id. The court, im rejecting Giles's appeal found the hearsay statements to have sufficient indicia of reliability. Giles, 772 P.2d at 194-95. In finding merit in Wright's appeal, the court concerned itself with the lack of procedural safeguards in the pediatrician's mterview and found it to be "presumptively unreliable." Wright, 775 P.2d at 1227. The Wright decision was appealed to the U.S. Supreme Court, which affirmed the Idaho Supreme Court's reversal of the conviction. See Idaho v. Wright, 110 S. Ct. 3139 (1990).

61. See Wright, $110 \mathrm{~S}$. Ct. at 3148 ("[W]ere we to agree that the admission of hearsay statements under the residual exception automatically passed Confrontation Clause scrutiny, virtually every codified hearsay exception would assume constitutional stature, a step this Court has repeatedly declined to take.").

62. Id. at 3146.

63. Id. (quoting Dutton v. Evans, 400 U.S. 74, 86 (1970)). 
Court found that the Confrontation Clause has a role in "restricting the admission of hearsay testimiony." 64 Hearsay rules and the Confrontation Clause, in the Court's view, are both designed to ensure that proffered testimony is rehable. ${ }^{65}$ For instance, the inedical exception to the hearsay rule is "based on a coinbination of two elements-trustworthiness and necessity."66 Extending the medical exception to include statements made by children to a wide range of professionals investigating sexual abuse charges undermines the medical exception's relationship to its underlying rationale.67 Ability to cross-examine the child does not recast an expert's repetition of an untrustworthy statement into a trustworthy statement. Therefore, the Wright Court's reasoning should not be interpreted to mean that had the same statements come in as a medical exception, instead of under a catchall exception, there would be no need to look for "particularized gnarantees of trustworthiness." First, that would be a mere relabeling of stateinents that would otherwise be held to be "presumptively unrehiable." Second, the extension of the medical exception to include statements made to mental health professionals investigating abuse allegations is a recent extension of the medical exception rule and is therefore not "firmly rooted." 68

Similarly, the Wright Court's requirement to look for "particularized gnarantees of trustworthiness" when the Confrontation Clause is implicated applies with equal force when the child/witness is available to testify. To illustrate, some of the social science research indicates that suggestive interviews will change children's cognitive memory of an

64. Id. at 4096 .

65. Id. at 4097.

66. Mosteller, supra note 38 , at 260 . For sources that discuss the rationale underlying hearsay exceptions, see id. at 260 n.7.

67. Id. at 283.

68. See Cassidy v. State, 536 A.2d 666 (Md. Ct. Spec. App.), cert. denied, 541 A.2d 965 (Md. 1988). The court in Cassidy was critical of expansions in the medical hearsay exception analysis, stating:

[F]or the first time in the history of hearsay law, the state of mind of the hearsay declarant is effectively ignored. . . . The mind of the deelarant had been the 'ever-fixed mark' from which our gaze never wandered. In [United States v.] Renville, [779 F.2d 430 (8th Cir. 1985), ] we are suddenly and unbelievably reckoning the value of the hearsay not upon the state of mind of the hearsay declarant, but upon the state of mind of the hearsay auditor.

Id. at 687 . The court then held that a two year old child lacked the maturity to understand or to appreciate the link between her statenients and proper treatunent. See id. at 680. For an excellent analysis of the underlying rationale of the nedical exception and how it should be applied to achieve nore accurate results, see Mosteller, supra note 38. The White decision also involved the admissibility of expert evidence under the medical exception when the Confrontation Clause is inplicated, but the Court specifically took "as a given ... that the testimony properly [fell] within the relevant hearsay exception[]." White v. Illinois, 60 U.S.L.W. 4094, 4096 n.4 (U.S. Jan. 15, 1992). Therefore, the Court did not examine the issue of whether the expert's testinony contained 'sufficient indicia of reliability' to be admissible. 
event. 69 In such a situation, no amount of cross-examination would shake a child's credibihty because that child would not be consciously lying. This situation particularly cries out for courts to evaluate expert testimony before admittimg it into evidence.

The Wright Court gave only minimal guidelines concerning circumstances that indicate rehiability. Significantly, the Court held that reliability-indicating circumstances include only those that surround the making of the statement. The Court thus rejected the State's argument that the totality of the circumstances that indicate reliability should include other evidence presented at trial that corroborates the truth of the expert's hearsay testimony. ${ }^{70}$ Although the Court refrained froin applying an "artificial hitmus test for the procedural propriety of professional interviews in which children make hearsay statements against a defendant,"71 it nonetheless identified five factors that it considered relevant to determine the admissibility of a child's statements inade during the interview. Those factors indicating rehability include spontaneity, consistent repetition, inental state of the declarant, use of terminology unexpected of a child of similar age, and lack of motive to fabricate. ${ }^{72}$ The Court stated, however, that those factors are not exclusive and that courts therefore "have considerable leeway in their consideration of appropriate factors." 73 When the Court applied those factors to the facts of the case, it found that the child's statements to the pediatrician were inadmissible because of the "[s]uggestive inanner in which [the pediatrician] conducted the interview ... [and the possibility] that '[i]f there is evidence of prior interrogation, proinpting, or inampulation by adults, spontaneity inay be an maccurate indicator of trustworthiness.' "74

69. See, e.g., Charles J. Brainerd et al., Fuzzy Trace Theory and the Development of Forgetting, in MoNographs FOR THE SOCIETY OF ReSEARCH IN CHILD DEVELOPMENT (forthcoming 1992) referred to in Ceci, infra note 164; see also Charles Brainerd \& Peter A. Ornstein, Children's Memory for Witnessed Events: The Developmental Backdrop, in SUgGestiBILTTY OF CHILDREN's RECOLLECrioNs supra note 35, at 10; infra note 198 and accompanying text.

70. See Wright, $110 \mathrm{~S}$. Ct. at 3148-50. The Court specifically rejected the State's contention that the medical evidence of abuse was a pertinent corroborating factor, stating that such medical evidence "sheds no light on the reliability of the child's [out-of-court allegations] regarding the identity of the abuser" and that " $[t]$ here is a very rcal danger that a jury will rely on partial corroboration to mistakenly infer the trustworthiness of the entire statement." Id. at 3151. The Court concluded that "the use of corroboratimg evidence to support a learsay statement's 'particularized guarantees of trustworthiness' would permit admission of a presumptively unreliable statement by bootstrapping on the trustworthiness of other evidence at trial." Id. at 3150.

71. Id. at 3148. By not creating an "artificial litmus test," the Court rejected the Idaho Supreme Court's requirement that the interview needed procedural safeguards such as videotaping.

72. Id. at 3150.

73. Id. For additional factors that courts should consider, see infra Part IV.

74. Wright, 110 S. Ct. at 3152 (quoting State v. Robinson, 735 P.2d 801, 811 (1987)). 
Therefore, the Supreme Court's decision in Wright to exclude the pediatrician's testimony because the interview was unduly suggestive specifically obligates courts to look imto the underlying validity of the investigative interview before admitting the child/witness's hearsay statements when that child will not testify in court. Furthermore, courts should evaluate the expert's testimony whether or not the child testifies because evidentiary rules assume that hearsay is presumptively unreliable unless it contains indicia of reliability.

\section{B. Expert Opinion Testimony That the Child/Witness Has Been Sexually Abused}

Because expert testimony in child sexual abuse cases is so important, it is essential that courts make a determination that the testimony is legally relevant and not misleading to the factfinder before admitting it into evidence. ${ }^{75}$

Federal Rule of Evidence 703 allows opinion testiniony by experts if it is based on facts or data reasonably relied upon by experts in the field. ${ }^{76}$ State rules have similar requireinents. ${ }^{77}$ Alternatively, some courts follow the Frye test, which requires that before evidence of a novel scientific principle is adinissible, the scientific primciple inust "have gained general acceptance in the particular field in which it belongs."78 In the context of child abuse, this ineans that the investigation needs to be conducted in a way that is recognized as valid by the social science community. ${ }^{79}$ Under Frye, the court inust make the preliminary examination of the expert's testimony to ascertain whether it is in accordance with a sufficiently reliable body of scientific or technical knowledge. ${ }^{80}$ If an evaluative interview has not been conducted properly, it follows that it cannot

75. See FED. R. EVID. 401 (“'Relevant evidence' means evidence having any tendency to make the existence of any fact that is of consequence to the determination of the action more probable or less probable than it would be without the evidence."); FED. R. EvID. 403 ("Although relevant, evidence may be excluded if its probative value is substantially outweighed by the danger of unfair prejudice, confusion of the issues, or misleading the jury, or by considerations of undue delay, waste of time, or needless presentation of cumulative evidence.").

76. FED. R. EVID. 703 (emphasis added).

77. See, eg., IDAho R. EvD. 703 ("The facts or data in the particular case upon which an expert bases an opinion or inference may be those . . of a type reasonably relied upon by experts in the particular field in forming opinions or inferences upon the subject.").

78. Frye v. Umited States, 293 F. 1013 (D.C. Cir. 1923).

79. There has been widespread criticism of how sexual abuse investigations are typically handled. See, e.g., WAKEFIELD \& UNDERWAGER, supra note 26; Quinn et al., supra note 5; Raskin \& Yuille, supra note 26, at 184. Therefore, courts should look outside the community of experts who handle child abuse investigations and look to see if the investigations conform to norms of the psychological cominunity as a whole.

80. See, e.g., United States v. Gould, 741 F.2d 45, 49 (4th Cir. 1984) (stating that it is reasonable to consider the issue of rehiability of the testimony as a foundational test of relevance). 
be reasonably relied upon as forming the basis of an opinion that the child has been abused. ${ }^{81}$

In many child sexual abuse trials, for example, the expert's testimony is wholly or partially based on the child's interaction with anatomically detailed dolls im the investigative interview. The social science literature, however, shows that courts have been premature in admitting such testiniony because the dolls have not proven to be reliable indicators of abuse. ${ }^{82}$ If the dolls are not reliable assessment tools, they are not legally relevant, and testimony based upon their use should be inadinissible. As Professor Mosteller has pointed out, "[r]elevancy exists if the principle involved itself is valid and the technique used is an effective method for producing the result indicated under the proper operation of that principle." 83 Because proponents of the use of dolls lave not demonstrated their scientific probativity and because there is a high degree of danger that their prejudicial inıpact substantially outweighs their probativity, all information gained froin the use of dolls during interviews should be excluded. ${ }^{84}$

81. For a discussion of the factors that a court should consider in determining whether an abuse investigation was properly conducted, see infra Part IV.

82. For a discussion of the studies that have examined the validity of anatomically detailed dolls as an assessment tool in determiming whether a child has been sexually abused, see infra Part III(A). Part III(A) concludes that the proponents of doll use have not convincingly demonstrated that the dolls are valid assessment tools.

83. Robert P. Mosteller, Legal Doctrines Governing the Admissibility of Expert Testimony Concerning Social Framework Evidence, LAW \& CONTEMP. ProBs., Autumn 1989, at 85, 102.

84. Some state courts have shared this conclusion; others have not. See, e.g., In re Ainber B., $236 \mathrm{Cal}$. Rptr. 623, 629 (Ct. App. 1987) (reversing dependency adjudication based upon doll-assisted testimony in absence of proof that doll testimony is admissible under Frye rule). The testimony that had been allowed in the trial court illustrates why the California appellate court was correct in holding that the testimony should have been inadmissible. In that case, the child demonstrated behaviors with the dolls that all of the studies have found to be normal interactions of nonabused children. See infra Part III(A)(2). At the trial level, the expert testified that he believed the child had been abused because:

During two of Dr. Raming's examinations Amber placed her index finger in the vaginal and anal openings of the doll and pushed and twisted her finger vigorously. According to Dr. Raming, Amber's behavior with the doll is fairly consistent with molested children. This is not the usual type of behavior one would see in children who are in a stage of age appropriate sex exploration.... [W] hen children this age describe or graphically demonstrate anal or vaginal penetration, it's pretty much assumed that the child learned that from experience and not from ... sex exploration with other children."

$236 \mathrm{Cal}$. Rptr. at 625 . Researchers have consistently found, however, that normal children actively explore and manipulate the dolls' gemitalia. See, e.g., Lois Jampole \& M. Kathie Weber, An Assessment of the Behavior of Sexually Abused and Nonsexually Abused Children with Anatomically Correct Dolls, 11 ChILd ABUSE \& NEGLECT 187 (1987).

Other state courts have allowed testimony where an abuse determination was made on the basis of a doll interview. See, e.g, State v. Fletcher, 368 S.E.2d 633 (N.C. 1988):

We cannot find that the use of anatomical dolls is mherently open to suggestiveness by the examiner.... [W] see no nced to have an expert evaluate the use of anatomical dolls or explain it to a jury; ... it is precisely because the use of the dolls can be readily understood 
The social science research supports excluding from evidence information gained from improperly conducted abuse investigations. If an investigation is conducted improperly, it is difficult, if not impossible, to determine whether the allegation is truthful.85 An improper investigation contaminates the court's truthseeking abilities and can forever obscure a court's ability to reach a proper determination of guilt or innocence. Lower courts that have allowed an expert to give an opinion that a child was sexually abused have implicitly assumed that the interview was properly conducted. ${ }^{86}$ By not rigorously examining the validity of the investigation, the courts have left it to the defense to challenge the prosecution's expert on cross-examination. Taking a more affirmative stance by excluding testimony under Rule 703 or the Frye test is the better approach because it safeguards the rights of innocent defendants, protects the rights of children who have been iniproperly labeled as abused, and provides a systemic remedy that will serve to improve the quality of abuse investigations.

\section{The Social ScIence Research Findings and Implications for Child Sexual Abuse Prosecutions}

Children who have been sexually abused must be encouraged to seek help and to confide im a trusted adult. However, inappropriate interviewing techniques can undermine the credibility of true accounts of abuse. Inproper investigations can also lead to false allegations, trials tainted by unreliable evidence, and to the conviction and imprisonment of innocent people. This Part discusses in depth the social science research regarding whether anatomically detailed dolls are reliable investigatory tools, whether children are suggestible and can be led to make false accusations of abuse, and problems of interviewer bias in investigatory interviews.

\footnotetext{
by everyone involved, especially the child, that they are so often employed in the investigation of child abuse.

Id. at 636-37.

85. See infra Part III.

86. See, e.g., In re Cheryl H., 200 Cal. Rptr. 789, 801 (Ct. App. 1984) (finding in a civil custody case that the expert's interviews with the child were "both a proper and sufficient basis for [the psychiatrist's] opinion [that the child] had been sexually abused"); State v. Hester, 760 P.2d 27, 3132 (Idaho 1988) (admitting expert testimony concluding that the child had been sexually abused); State v. Bailey, 365 S.E.2d 651, 657 (N.C. Ct. App. 1988) (ruling that expert inay testify that child had been sexually abused without violating rule against giving opinion on credibility of witness or concerning guilt of defendant). But see Allison v. State, 353 S.E.2d 805, 808 (Ga. 1987) (stating that had defense counsel objeeted, testimony by expert witness that the child/witness had been sexually abused-based upon two interviews with the child, observations of her, and discussions with the child's counselor-wonld have been inadmissible).
} 


\section{A. The Controversy Surrounding the Use of Anatomically Detailed} Dolls in Investigative Interviews

Using anatomically detailed dolls ${ }^{87}$ to encourage children to recount abuse is a highly controversial technique. Increasingly, research has shown that the dolls are unreliable assessinent tools. This Section will discuss all the studies that have examined the rehability of anatonically detailed dolls as an imvestigatory tool im child sexual abuse cases.

1. Overview of the Reliability Problems Associated with Anatomically Detailed Dolls. Many agencies rely on anatomically detailed dolls when diagnosing sexual abuse in young children. According to one survey, ninety-four percent of child protective workers and forty-six percent of law enforcement officers presently use or intend to use anatoinical dolls in their assessments of sexual victimization of young children. ${ }^{88}$ The use of dolls at these agencies became prevalent despite an absence of baseline data about how non-sexually abused children interact with the dolls. ${ }^{89}$ The dolls are used because investigators assume that they will assist a child in reporting an abusive experience. If a child is reluctant or unable to verbalize einbarrassing events, it is thought that she will demonstrate with the dolls what has happened to her.90

Those who oppose the use of the dolls in investigative interviews claim that the dolls theinselves suggest sexual theines in a child's play. That is, the children interact with the dolls in exphicitly sexual ways whether or not the children have any sexual experience. Gabriel states:

Many persons working in the child protection field are untrained in play therapy and do not know about the projection-evoking properties of toys. The result has been that inaterial produced by children in this inanner can appear to confirm suspicions of sexual abuse when it may actually be no more than a normal reaction to the dolls and the situation.91

87. Anatomically detailed dolls are usually made of plastic or cloth, are about 20-25" in length, have thread for pubic hair, and have mouths with tongues. The female dolls have protruding breasts, and red anal and vaginal openings. The male dolls have penises, scrotums, and red anuses.

88. Barbara W. Boat \& Mark D. Everson, Use of Anatomical Dolls Among Professionals in Sexual Abuse Evaluations, 12 CHILd ABUSE \& NEGLECT 171, 173 (1988).

89. See Levy, supra note 28 , at 400 (pointing out that 129 civil and criminal appellate cases concerning the use of anatomically detailed dolls had already been decided before the first study of any kind was publicized on the validity of the dolls).

90. Alayne Yates \& Lenore Terr, Anatomically Correct Dolls: Should They Be Used as the Basis for Expert Testimony?, 27 J. AM. ACAD. Child \& Adolescent Psychiatry 254, 256 (1988) (debate between two child psychiatrists on the scientific reliability of anatomicaliy detailed doll interviews).

91. R.M. Gabriel, Anatomically Correct Dolls in the Diagnosis of Sexual Abuse of Children, $3 \mathrm{~J}$. MELANIE KLEIN Soc'Y 40, 42 (1985), quoted in WAKEFIELD \& UNDERWAGER, supra note 26, at 203-04. 
King and Yuille point out that "the dolls serve the function of a suggestive question with young children. The genitals and orifices of the dolls suggest a play pattern to children, and that play may be misinterpreted as evidence for abuse."92 Furthermore, although protocols have been developed about how to interview with the dolls, these protocols vary and most agencies do not follow thent. Wakefield and Underwager say that "[w]ithout standardized procedures there is no way of determining what effect the procedures have on the responses ehicited."93 Some professionals acknowledge that they have used the dolls in a manner designed to encourage-even to impel-children to make accusations. ${ }^{94}$

Another reason that use of the dolls has beconie so widespread is that they seein to provide a shortcut means of getting to the truth of the matter. Many researchers contend that this is inappropriate because there can be no shortcut means of determining whether a child has been abused. ${ }^{95}$

Even proponents of the dolls admit that there are severe limitations to their use because the people who use them are poorly trained.96 In one survey of professionals who use the dolls, the researchers found that only

92. Mary Ann King \& John C. Yuille, Suggestibility and the Child Witness, in CHILDREN's EYEWITNESS MEMORY, supra note 35 , at 31.

93. WAKEFIELD \& UNDERWAGER, supra note 26, at 208; see also Sue White et al., Interviewing Young Sexual Abuse Victims with Anatomically Correct Dolls, 10 CHILD ABUSE \& NEGLECT 519, 520 (1986) ("[One] of the more pressing probleins created by the use of the anatomical dolls [is] the lack of structured procedures to guide the interview process.").

94. See, eg., Gillian Douglas \& Christine Willmore, Diagnostic Interviews as Evidence in Cases of Child Sexual Abuse, 17 FAM. L. 151 (1987) (reporting on one agency's use of the dolls):

Since children are often very reluctant to talk about the matters in issue, the interviewer applies a degree of coaxing and pressure on the child to overcome this reticence. This encourageinent to answer may involve leading or hypothetical questions or questions designed to elicit a different answer to one already given. It is felt by the clinic that such pressure is necessary to enable the child finally to inake stateinents against another family meinber; as one of the chinic staff has put it, it is necessary to match the trauma which the child has suffered through the abuse by placing equal pressure on the child to talk about what has occurred.

Id.

95. See, e.g., Yates \& Terr, supra note 90:

For diagnostic purposes in ordinary child psychiatric practice, ... there is nothing superior to unstructured play and open-ended questions. These elicit the most, the "cleanest," information from youngsters.

These open-ended tecliniques take time, and they require ligh levels of traiming and expertise to administer. Sexually anatonically correct dolls, on the other hand, seein to allow for shortcuts both in time and in training .... The anatomically correct dolls make but one request, "play sex." Many children secin to respond to thein at once, even when untrained criminal imvestigators administer the doll sessions. The additional and tempting codicil: "Tell me, Did soineone do solnething like this to you?" gathers up even more fast answers froin certain children. And so a large, enthusiastic cohort of law enforceinent and social personnel have come to rely upon this method for the main, and in some instances the only, inethod of imvestigation when preschoolers are alleged to have been sexually abused.

Id. at 256.

96. See id. 
forty-three percent of the child protection workers and forty-seven percent of the law enforcement officers had even minimum training in the use of the dolls. ${ }^{97}$ About three-quarters of the mental health professionals, but only one-quarter of the physicians, reported any training. ${ }^{98}$ Very few doll users had access to a manual or to a set of guidelines.99 The situation is actually worse than this because the researchers defined training as including any written or taped instructions, workshops or courses, presentations at professional ineetings, or simply discussions with a supervisor or colleague. ${ }^{100}$ Furthermore, inost interviewers had only one session with a child to determine whether that child had been abused.101 This situation is even more distressing when one considers that expert testimony is often based on conclusions obtained solely from a child interview conducted with anatomically detailed dolls. ${ }^{102}$

A survey by researchers Boat and Everson revealed two more highly troubling findings-professionals had widely varying views as to what they would consider indicative of abuse. The survey asked the evaluators what they wonld endorse as convincing evidence of sexual abuse in three to five year old children. They found wide variation among the professionals as to what sorts of behaviors of the child would be "very convincmg" evidence of abuse and what sorts of interactions with the dolls wonld be considered normal and not indicative of abuse. Their survey also shows substantial percentages of the professionals found certain interactions with the dolls to be indicative of abuse, where most of the hiterature is in agreement that these are normal behaviors. For instance, all of the studies demonstrate that children with no known history of abuse actively explore the dolls' gentals, including digital penetration of the orifices. ${ }^{103}$ Despite this, many of the child protection workers in Boat's survey would find some of these explorations to be indicative of

The majority of individuals who use the anatomically correct dolls are employed by public agencies and have little or no training in child development, child assessment, mental health, or human sexuality. Their credentials often consist of a weekend workshop in sexual trauma assessment. Yet the dolls are only as good as the people who use them. We need thoroughly qualified, skilled examiners who are comfortable in the playroom. Examiners need enough time to develop a relationship with the child. The child should spontaneonsly explore the dolls and their gemitalia if the results are to be relatively uncontaminated. Examiners must have the ability to elicit a sexual history from the child so that the data obtained from the child's play witl the dolls can be placed in perspective.

Id. at 255.
97. Boat \& Everson, supra note 88 , at 173.
98. Id.
99. Id.
100. Id.
101. Id. at 174 .
102. See id.
103. See, e.g., Jampole \& Weber, supra note 84, at 190. 
abuse. Table One illustrates what the investigators thought were abuserelated behaviors. ${ }^{104}$

The controversy and the concerns expressed even by proponents of dolls mean that it is crucial that legal professionals examine and evaluate the empirical research on anatomical dolls before courts should admit expert testimony based on doll-use interviews.

2. Description and Discussion of the Anatomical Doll Studies. Because of the controversy surrounding the use of the dolls, researchers have designed a number of studies to look at how abused and nonabused children interact with the dolls, whether the dolls themselves are suggestive of sexual play, and how evaluators categorize children based upon their interactions with the dolls. There have ouly been eleven studies of anatormical dolls, and this Note will discuss all of thein. The studies, taken together, show that the dolls have failed to be rehiable indicators of abuse.

a. Can evaluators accurately classify children as abused or nonabused when observing children's interactions with the dolls? One highly important question pertaining to the rehability of the dolls is whether an evaluator, who is unaware of the abuse status of the children, can accurately identify those who have been abused by how the children

104. Boat \& Everson, supra note 88 , at 171 :

TABLE ONE

JUDGMENTS ABOUT NORMALCY OF BEHAVIORS OF 2-5 YEAR OLDS WITH ANATOMICAL DOLLS

Child's Behavior with the Dolls

\begin{tabular}{|c|c|c|c|c|}
\hline & $\begin{array}{c}\text { Child } \\
\text { Protection } \\
\text { Worker } \\
\text { \% Normal }\end{array}$ & $\begin{array}{l}\text { Mental } \\
\text { Health } \\
\text { Pro } \\
\% \text { Normal }\end{array}$ & $\begin{array}{c}\text { Doctor } \\
\% \text { Normal }\end{array}$ & $\begin{array}{c}\text { Law } \\
\text { Enforcement } \\
\text { \% Normal }\end{array}$ \\
\hline (lying & $\begin{array}{l}98 \\
95 \\
98 \\
97 \\
94 \\
89 \\
48 \\
48\end{array}$ & $\begin{array}{r}94 \\
94 \\
100 \\
100 \\
100 \\
82 \\
59 \\
29\end{array}$ & $\begin{array}{r}100 \\
85 \\
92 \\
92 \\
92 \\
77 \\
46 \\
39\end{array}$ & $\begin{array}{r}100 \\
94 \\
75 \\
88 \\
63 \\
75 \\
50 \\
6\end{array}$ \\
\hline & $\begin{array}{r}14 \\
9 \\
9 \\
9 \\
9\end{array}$ & $\begin{array}{r}12 \\
6 \\
6 \\
6 \\
6\end{array}$ & $\begin{array}{l}23 \\
15 \\
15 \\
15 \\
15\end{array}$ & $\begin{array}{r}21 \\
13 \\
13 \\
6 \\
6\end{array}$ \\
\hline
\end{tabular}

Undressing the doll

Staring at the doll's gemitals

Touching dolls' breasts

Touching dolls' gemitals

Touching dolls' anal area

Showing dolls kissing

Avoiding dolls or anxious behavior

Placing dolls on top of each other (lying

down)

Digital penetration by child to doll

Showing vaginal penetration

Showing anal penetration

Showing oral-genital contact

Showing genital-genital contact

Nonabused children have demonstrated all these behaviors with the dolls. Most children stick their fingers in the orifices and yet this is seen as not normal by $86 \%$ of the child protection workers, $88 \%$ of the mental health professionals, $77 \%$ of the doctors, and $79 \%$ of the law enforcement personnel. 
interact with the dolls. Only one study, by researchers Realmuto, Jensen, and Wescoe, ${ }^{105}$ has been conducted on this issue. In the study, the evaluator, who was unaware of each child's abuse status, had high error rates in categorizing the children. She had a sixty-seven percent falsepositive rate (sixty-seven percent of those she said were abused were not abused). The researchers concluded that an evaluation based on the use of the dolls cannot replace a coinplete and comprehensive psychiatric evaluation. They concluded that "[w]ork with children is a process of cumulative understanding so that shortcuts and abbreviated assessments ... raise questions regarding ethics and standards for inental health professionals."106

\section{b. Do abused and nonabused children interact with the dolls} differently? Five studies have coinpared how nonabused and abused children interact with the dolls. All of these studies found that a significant percentage of the nonabused children engaged in sexuahized play with the dolls. In the study conducted by McIver, Wakefield, and Underwager, ${ }^{107}$ the researchers were unable to distinguish any differences in the behavior and responses to the dolls between the abused and the nonabused children. Forty-four percent of the nonabused and thirty percent of the abused spontaneously talked about and/or touched the

105. Realmuto, supra note 12. Fifteen children, three to eight years of age, were recruited for participation in a structured interview with the dolls. Five nonclinic controls (children who werc recruited from a group of children imvolved in a longitudinal study of normal child developinent), four psychiatric nonabused controls (children who were being evaluated by the clinic for hyperactivity and depression but who had no history of sexual abuse), and six sexually abused cliildren participated. Designation as sexually abused was decided after review of a coinpreliensive psychiatric evaluation and court and police records by two independent clinicians. Corroboration from all sources of information was necessary for a case to be assigned to the sexually abused group. All subjects were interviewed for 20 minutes by a sernior female child psycliatric resident who was well acquainted with the interview protocol and who was blind to the abuse status of the children. None of the children was asked abuse-related questions.

106. Id. at 745 .

107. William Mclver et al., Behavior of Abused and Non-abused Children in Interviews witlı Anatomically-Correct Dolls (1987) (unpubhished manuscript), cited in WAKEFIELD \& UNDERWAGER, supra note 26, at 206-07. In that study, the sample consisted of 50 nonabused children and 10 abused children. The interviewer was aware of the abuse status of the children, but two raters who categorized the children were not. The abused children had never before been interviewed by counselors, police, or anyone else outside their imunediate families. The children were interviewed individually and encouraged by open, non-leading questions to say whatever they wanted and to do whatever they wanted with the dolls. Seven of the children (six nonabused and one abused), following the initial portion of the interview, were asked deliberately leading questions, cues, modeling, and reinforcement in an atteinpt to elicit sexual behaviors with the dolls. The interviewer asked questions such as "Can you show ine?" "How else could they go together?" and then reinforced the responses with "Uh huh," and "Anytling else?" The researchers said the behaviors engaged in by the interviewer in this portion of the interview were sinilar to those observed in typical videotaped interviews of allegedly sexually abused children. 
dolls' genitals, and sixty-two percent of the nonabused and fifty percent of the abused placed the dolls in clear sexual positions and/or played with the dolls in an overtly aggressive manner. ${ }^{108}$ Seven of the children were asked leading questions; of these, six responded to the cueing. ${ }^{109}$ As this portion of the interview progressed, the children contimued to denionstrate inore and inore aggressive and sexual behaviors. ${ }^{110}$

In the McIver study, the researchers found it noteworthy that the sexual and aggressive behavior was obtained with comparatively subtle questions and cues. ${ }^{111}$ In a typical real-world interview involving the dolls, a large proportion of the interview consists of leading questions, modeling, and selective reinforcement. ${ }^{112}$ These researchers concluded that the dolls should not be used because they provide a inodeling effect. The researchers said that "[a]11 of the social learning hiterature shows that one of the inost powerful ways of teaching children is by inodeling. ... The child is being taught to produce the responses favored and reinforced by the interviewer." 113

A study conducted by Debra Colin ${ }^{14}$ reached results similar to those of the McIver study. This study compared thirty-five nonabused children to a group of thirty-five children who were suspected to have been abused. The level of sexualized play with the dolls was similar for both groups. Of the thirty-five children who were suspected to have been abused, four children inserted their fingers into the dolls' genital/anal orifices, one demonstrated masturbation, and two similated intercourse. ${ }^{115}$ Likewise, of the thirty-five nonabused children, nine inserted their fingers into the genital/anal orifices, one deinonstrated intercourse, and six rubbed the dolls together. ${ }^{116}$ The researchers concluded that the differences between the two groups were inconclusive and that "no clearcut profile of doll play by children referred for evaluation of sexual abuse was estabhished."117

108. This play included placing one doll on top of another doll in the "missionary position," sticking a male doll's penis in one of the openings (oral, vaginal, anal), wrestling, spanking, throw$\mathrm{mg}$, or hitting the dolls or having one doll do these to another doll. Id. at 207.

109. Id. at 207.

110. Id. at 208.

111. Id.

112. Id.

113. Id. at 209-10.

114. Debra S. Cohn, Anatomical Doll Play of Preschoolers Referred for Sexual Abuse and Those Not Referred, 15 ChILd ABUSE \& NEGLECT 455 (1991). Thirty-five two- through six-year-olds referred to a lospital child abuse clinic were compared to 35 controls who were matched on sex, race, and age. Id.

115. Id. at 461 .

116. Id.

117. Id. at 465 . 
Three other studies found differences in how the majority of abused children and nonabused children interacted with the dolls, but some of thein are difficult to interpret because the researchers failed to report specifically how the children interacted with the dolls.118 In those studies that described the children's behaviors, significant percentages (up to twenty percent) of the nonabused children interacted sexually with the dolls. ${ }^{119}$

The first study was conducted by White, Strom, Santilli \& Halpm. ${ }^{120} \mathrm{It}$ found that inost of the nonabused children interacted with the dolls in a way that was either not suspicious or only ambiguously suspicious for abuse, and that the children who were suspected of having been abused interacted with the dolls in a way that was either ambiguously suspicious or that aroused low-level suspicion of abuse. ${ }^{121}$ The researchers concluded that interviewing children with anatomical dolls using a structured protocol was helpful in differentiating between abused and nonabused children. ${ }^{122}$ Unfortunately, the report does not describe specific behaviors engaged in by any of the children. ${ }^{123}$ Another problem with the study is that the researchers failed to substantiate whether the children in the sexually abused group had actually been abused. ${ }^{124} \mathrm{Be}-$ cause of these shortcomings, this study at best provides weak support for the validity of doll-based interviews. Furthermore, this study specifically addressed the need for a structured interview protocol and does not support in any way the validity of an unstructured doll interview.

The second study, conducted by August and Forman, ${ }^{125}$ which has been interpreted by some professionals as supporting doll use provides

118. White, supra note 93; Robin L. August \& Bruce D. Forman, A Comparison of Sexually Abused and Nonsexually Abused Children's Behavioral Responses to Anatomically Correct Dolls, 20 Child Psychiatry \& Hum. Dev. 39 (1989); Jampole \& Weber, supra note 84.

119. Jampole \& Weber, supra note 84 , at 190.

120. White, supra note 93 . The study compared 25 nonabused children with 25 children who had been referred to a child protection agency because of a suspicion of abuse-i.e., the abuse was not actually known to have occurred. The children were between the ages of two and five years old. Almost all of the nonabused children were white, froin intact families, and the children of the employees of a research hospital. The allegedly abused children were racially diverse and from diverse living situations. The researchers created a structured doll interview protocol that required the interviewer to be blind to the details of a child's abuse history. Id. at 521 .

121. Id. at 523-26.

122. See id. at 528.

123. Further problems with the White report are revealed by the Everson and Boat study which found that children of different socioeconomic/racial baekgrounds unay have different normative responses to the dolls than do white, middleclass children. Therefore, this study may have made invalid comparisons. See Everson \& Boat, infra note 137, at 740-41.

124. See White, supra note 93 , at 520.

125. August \& Forman, supra note 115 . The researchers compared 16 allegedly abused girls to 16 nonabused girls. The girls were five to eight years old. The children who were suspected of liaving been abused were drawn from one of four evaluation or treatınent programs for sexually 
some evidence that abused and nonabused children behave differently toward the dolls when left alone with them. The two groups displayed different levels of aggression toward the dolls, and a different number of references to the dolls' "private parts." 126

This study cannot be said to support the theory that children who have been sexually abused interact with the dolls differently than nonabused children for two reasons. First, the researchers did not describe the specific behaviors observed. Second, when a researcher was present in the room with the children, the study found that there was no statistical difference betwecn the two groups in aggression toward the dolls or in references to "private parts," but that there were statistical differences in their degrec of avoidance of the dolls. ${ }^{127}$ The findings thus conflict depending on the setting, children alone or researcher present, and also indicate that an interviewer's presence may cause children to alter their behavior with the dolls.

The last study to coinpare abused and nonabused children's interactions with the dolls found that twenty percent of the nonabused children, two of the ten studied, interacted sexually with the dolls ${ }^{128}$ and that ninety percent of the abuse group demonstrated sexual behaviors with the dolls. In the nonabuse group, an eight year old child demonstrated sexual intercourse between herself and a doll and a four year old demonstrated oral sex between herself and a doll. ${ }^{129}$ The researchers qualified their own findings by noting that the abused children had been interviewed previously regarding abuse. These prior interviews may have affected their behavior in the research setting. ${ }^{130}$ Although there were substantial differences in the percentage of children who demonstrated

abused children in Dade County, Florida and therefore had already undergone abuse-related interviews prior to this study. The children were allowed to interact alone with the dolls and then later with an interviewer.

126. Id. at 43.

127. See id.

128. Jampole \& Weber, supra note 84 , at 190 . The study coinpared 10 allegedly sexually abused children with 10 children who were not abused, ranging in ages froin three to eight years old. The children coinprising the abuse group had been determined to have been abused after a series of investigative interviews by the Louisiana Departinent of Health and Human Resources and/or by the Jefferson Parish Sheriff's Office. None of them had been interviewed with the dolls before this study. In the study, the observer was blind to the abuse status of the child (although the person who interacted with the dolls was not), but the researchers did not report the accuracy of the observer's categorization of the children. The specific behaviors engaged in by both sexually abused and nonsexually abused children included penetrating the dolls' genitals with fingers, deinonstrating intercourse between the doll and child, deinonstrating dolls having oral sex with child, and deinonstrating intercourse between the dolls.

129. The authors considered penetration of the doll with the child's fingers to be "a natural wish to explore new playthings" and did not include this behavior as a sexual act. Id. at 190.

130. Id. 
sexual behaviors in each of the two groups, the fact that twenty percent of nonabused children interacted sexually with the dolls deinonstrates the need for extreine caution in adimitting testimony concerning a child's interactions with the dolls.

c. What are the normative responses of nonabused children when interacting with anatomically detailed dolls? Four studies exclusively examined how nonabused children interact with the dolls. These studies came to widely varying conclusions as to the validity of the dolls as investigative tools. For exainple, Gabriel, who observed nineteen nonabused children with the dolls and other toys, found that the "children showed several behaviors which could have been interpreted by other interviewers as indicating likely sexual abuse. Around half of the children showed overt interest in the genitals and/or unusual interactions with the genitals." 131 The researcher concluded: "[O]n the evidence of the dolls alone, when used as part of a 'fishing expedition' exercise, the suspect will almost always be found 'guilty', especially if the examiner is already biased in that direction." 132

Other researchers, although not rejecting outright the notion that the dolls may someday prove to be rehable, have concluded that research on anatomical dolls is still too inconclusive to permit the dolls to be used as a diagnostic tool. In a study of ninety-two nonabused children conducted by Glaser and Collins, ${ }^{133}$ five children engaged in exphicit sexual play, ${ }^{134}$ five children showed aggression between the dolls, and six showed affection between the dolls.135 The researchers concluded: "At present, insufficient information exists to permit play with the dolls to be regarded as a chirically rehable screening test for sexual abuse."136

131. Gabriel, supra note 91 , at 210.

132. Id.

133. Danya Glaser \& Carole Collins, The Response of Young, Non-Sexually Abused Children to Anatomically Correct Dolls, 30 J. CHILd Psychol. \& Psychiatry 547 (1989). Their sample consisted of 92 nonabused English two to six year olds, of which five refused to play with the dolls. Most of the children were between the ages of three to five, $52 \%$ were girls, and $48 \%$ were boys. Id. at 550. The children were encouraged to play with the dolls, to undress the dolls, to name the doll's body parts, and to identify two functions of each body part. Id. at 552-53. For most of the play session, the children engaged in free play with the dolls. Id.

134. It was later learned, however, that three of these children had seen either some pornographic hiterature or a teenage sibling having intercourse. Id. at 556-57. One four year old girl who had no previous exposure to sexual materials attempted to join the genitalia of the dolls and was giggly and excitable when she played with the dolls. Id. at 556 .

135. Id. at 557.

136. Id. at 559 . 
The doll study conducted by Everson and Boat ${ }^{137}$ indicates that children from diverse racial and socioeconomic backgrounds may have different normative responses to the dolls than do white, middleclass children. Their study of 209 nonabused children, ranging in age from two to five years old, found that a significant minority of the nonabused children engaged in sexualized play with the dolls. For example, twentyfive percent of the five year olds placed the dolls in suggestive positions and sixteen percent of the five year olds placed them in clear intercourse positions. ${ }^{138}$ A few of the children placed an unclothed doll up to their own genitals and actually simulated intercourse through inovement. ${ }^{139}$ The most cominon child-to-doll activity involved the child mouthing a doll's penis. ${ }^{140}$ Everson and Boat also found that explicit sexualized play was found to be highest among the older, poor, black inales.141 Their findings indicate that differential norms nay be required for interpreting the anatomical doll play of children from varying backgrounds.

Everson and Boat, lowever, came to a troubling conclusion-that their study stands as "substantial evidence agamst the argument that anatomical dolls are too suggestive for use in sexual abuse evaluations with young children." 142 The conclusion is disturbing because many of these nonabused children would have been identified as abused by the child protection workers. For instance, forty-one percent of the five year olds placed the dolls in eitler suggestive or clear intercourse positions. If one compares this to the survey of abuse investigators conducted by Boat and Everson, ninety-one percent of the child protection workers would have identified these children as abused. ${ }^{143}$ Furthermore, the children in the study were not subjected to a suggestive interview environinent other

137. Mark D. Everson \& Barbara W. Boat, Sexualized Doll Play Among Young Children: Implications for the Use of Anatomical Dolls in Sexual Abuse Evaluations, 29 J. AM. ACAD. CHILD \& ADOLEscent Psychiatry 736 (1990). The 209 children studied were recruited from diverse socioeconomic and urban/rural backgrounds. Sixty-eight percent of the children were white and $32 \%$ were black. The researchers established an interview protocol that included periods of free play and structured questions from the interviewer. Id. at 738-39. During free play exploration of the dolls, the children were asked to, "Show ine what the dolls can do together." The researchers were particularly interested in whether the children would engage the dolls in suggestive or clear sexual positioning. Suggestive intercourse positioning was defined as deliberate placement of unclothed dolls in sexual positions but without insertion of the penis, verbal descriptions of intercourse, or sexual moventent of the dolls. Clear intercourse positioning was defined as deliberate placement of unclothed dolls in a sexual position with either insertion of penis in vagina, mouth, or anus; verbal description of intercourse; or sexual movement ("humping," as the researchers put it). Id. at 740.

138. Id.

139. Id.

140. Id.

141. Id. Twenty-seven percent (four of 15) of the older, poor, black inales had the dolls demonstratimg clear intercourse positioning.

142. Id. at 741.

143. See supra note 104, Table One. 
than the cue, "Show me what the dolls can do together,"144 and yet a substantial number, fifty-eight of the 209 children, put the dolls in suggestive or clear intercourse positions. ${ }^{145}$

The Sivan study is the only study to find that the suggestiveness of the dolls is neghigible or nonexistent. ${ }^{146}$ These researchers attempted to determine what children would do in free play with the dolls and intentionally did not try to resemble a child abuse investigation. These researchers found that although the sexual body parts of the dolls were inspected by many children, role playing of exphicit sexual behavior was not observed. ${ }^{147}$ They also found that less than one percent of the observed interactions were aggressive. ${ }^{148}$ It is important to note, however, that the researchers exphicitly did not attempt to find how children would respond to the dolls in an environment that resembled an abuse investigation. Therefore, it is unknown how these children would have interacted with the dolls if they had played with the dolls while being asked abuserelated questions.

d. Do misleading questions affect children's accuracy when they use anatomical dolls to aid in responding to the questions? One study, conducted by Goodman and Aman, examined whether doll-use affects children's answers when asked misleading and suggestive questions about an event. ${ }^{149}$ In this study, eighty children, ages three and five years old, experienced a social interaction with a male confederate and were later tested under one of four recall conditions: reenactment with

144. Everson \& Boat, supra note 137 , at 739 .

145. Id. at 740 .

146. See Abigail B. Sivan et al., Interaction of Normal Children with Anatomical Dolls, 12 CHILD ABUSE \& NEGLECT 295 (1988). One hundred forty-four middleclass children, ranging in age from three to eight years, were observed in a playroom containing the dolls under four conditions: with an adult present and the dolls dressed; without an adult present and the dolls dressed; with an adult present and the dolls undressed; and without an adult present and dolls undressed. Id. at 296-98.

147. Id. at 302 .

148. Id. at 301 .

149. Gail S. Goodman \& Christine Aman, Children's Use of Anatomically Detailed Dolls to Recount an Event 61 CH1LD DEV. 1859 (1990). Specifically, the researchers found that misleading and suggestive questions affected the children's accuracy in all age ranges and all conditions, and that the inaccuracies increased when the dolls were used. Three year olds' maccurate responses ranged from $33 \%$ when asked specific, but not misleading, questions in the no-doll condition, up to $48 \%$ when they were asked specific questions in the anatomical doll condition. Id. at 1865 (Table 2). When the three year olds were asked misleadimg questions in the anatomical doll condition, their inaccurate responses increased to 52\%. Id. at 1866 (Table 3). The five year olds fared better. When they were asked specific questions in the no-doll, no cue condition, $26 \%$ responded inaccurately. Those inaccurate responses declined slightly to $23 \%$ when asked specific questions in the anatomical doll condition. Id. at 1865 (Table 2). When the five year olds were asked misleading questions in the no-doll, no-cue condition, $20 \%$ responded inaccurately. Their inaccurate responses in the misleading question, anatomical doll condition increased slightly to $21 \%$. Id. at 1866 (Table 3). 
anatomically detailed dolls, reenactment with regular dolls, free recall with visual cues, or free recall without visual cues. The children were asked a variety of specific and misleading questions, some of them dealing with acts associated with abuse. ${ }^{150}$ The researchers found that any sort of cuemg negatively affected some children's accuracy and that the three year olds were more suggestible than the five year olds. ${ }^{151}$ Furthermore, the use of the anatomical dolls had the most adverse impact on the accuracy of their accounts: Fifty-two percent of the three year olds and twenty-one percent of the five year olds responded inaccurately when asked misleading questions when the anatomical dolls were used.152 Goodman attributes soine of the inaccuracy to the fact that some of the children did not understand the term "private parts." However, this does not account for the fact that the three year olds' inaccurate answers increased when the anatomical dolls were used-that is, thirty-six percent responded inaccurately to misleading questions in the no-doll, nocue condition; that percentage increased to fifty-two when the anatomical dolls were used.

In synthesizing the findings of these various studies, it is apparent that the proponents of doll use have not demonstrated that the dolls are a valid assessment tool. Before the use of the dolls can be established as a rehiable indicator of abuse, researchers need to demonstrate that evaluators can accurately categorize children as abused or nonabused. ${ }^{153}$ Specific procedures would have to be adopted and followed by investigators ${ }^{154}$ to ensure that there is strong interrater reliability in how childien are categorized. ${ }^{155}$ In addition, further studies need to be performed on the differences in normative responses of children from diverse socioeconomic and racial backgrounds. ${ }^{156}$ Based on these studies, which represent the scholarly research in this area, it is unrealistic for child protection teams to use the dolls-particularly as their primary or only means of gathering inforination about a child's alleged abuse. No one

150. The misleading questions included, "He took your clothes off, didn't he?," "He kissed you, didn't he?," and "How inany times did he spank you?" Id. at 1866.

151. Id.

152. Id.

153. See supra notes $105-14$ and accompanying text. The Realmuto study found that the categorizer had a $67 \%$ false-positive rate, and the McIver study was unable to differentiate behavioral responses of abused and nonabused children.

154. This is a basic requirement of any diagnostic test. See, e.g., 1 JAY ZISKIN, CopING WITH Psychiatric and Psychological Testimony 206 (3d ed. 1981).

155. See id. at 251-88. The Boat and Everson survey of child abuse investigators, see supra note 88 , demonstrates that this is a particularly acute need.

156. See Everson \& Boat, supra note 137. 
assessment tool can possibly carry that burden. ${ }^{157}$ For example, Rorschach imk blots ${ }^{158}$ may be valid in helping to determine an individual's inental condition, but no ethical clinician would rely on that test alone to assess a person's mental state. In fact, the widespread use of the anatoinical dolls indicates that child protection workers themselves have overvalued their probativity. ${ }^{159}$ Whether or not children are suggestible when the dolls are used, there is a strong danger that abuse evaluators read too much into children's exploration and interaction with the dolls, consequently inaccurately labeling nonabused children as abused. 160

\section{B. The Research on Children's Suggestibility}

Although child advocates have stated that leading questions are a necessary component of getting a full disclosure of abuse froin a young child, ${ }^{161}$ the research on children's suggestibility indicates that suggestive interviews increase the likelihood of false allegations. Proponents of leading questions, however, deny that leading questions influence a child's answer. Professor Myers has stated that "the developmental limitations of young children sometimes necessitate careful use of specific and, at times, leading questions. Furthermore, inodern research discloses that young children are more resistant to suggestive questioning

157. See 1 Ziskin, supra note 154, at 207.

158. In the Rorschach test, individuals are asked to describe in detail their impressions of a series of inkblots. The subjects' interpretations of inkblot shapes are used as keys to understand dimensions of the subjects' personalities. ANN L. WEBER, INTRODUCTION TO PSYCHOLOGY 106 (1991).

159. See Yates \& Terr, supra note 90. Dr. Terr recounts an experience that illustrates this point:

I watched a television tape recently that shows a policeman administering a sexually anatomically correct doll interview to a thrce year old in a small rooln furnished with only two chairs and one set of dolls. When the youngster hesitated a moinent after fiddling with the genitalia of the adult male doll, the officer asked, "Did your daddy do anything like that to you?" Sucli a question, asked in the midst of such stimulating, unusual play, might, I think, elicit any kind of answer from a confused young child, an answer, perhaps, having little to do with this particular youngster's life experiences. On the tape I watclied, the boy answered, "Yes, Daddy did," and the prosecutor who presented the tape told us that he had obtained a criminal conviction of the boy's father on the basis of this. But, was the boy rcally sexually abused? I felt at a loss to know.

Id. at 256.

160. See supra note 104, Table One.

161. See, eg., BROSS ET AL., supra note 23, at 182 (stating that suggestive and leading questions are appropriate interviewing techniques for young children); Kathleen C. Faller, Is the Child Victim of Sexual Abuse Telling the Truth?, 8 CHILD ABUSE \& NeGLECT 473 (1984) ("If the child does not provide detail of sexual abuse spontaneously, sonetimes it can be elicited by asking sucl questions as 'Did lie toucli your privates?' 'Did he put his finger inside?' A less preferable alternative is for the evaluator to relate what she/he thinks happened and ask the child to respond 'Yes' or 'No' to each statement."); see also WAKEFIELD \& UNDERWAGER, supra note 26, at 36 (finding that, after reviewing over 100 videotapes of various investigative interviews across the country, leading questions and other types of error-inducing questioning-including closed questions, modeling, pressure, rewards, aids, and paraphrasing-occur from $50 \%$ to $80 \%$ of the time in the typical interview of the child witness). 
than many adults believe."162 Professor Myers's assertion, however, is not supported by the research evidence concerning suggestibility. One can reach his conclusion only by reading the research selectively and by ignoring the studies that show that there are potentially serious social and cognitive hazards connected with interviewing young children with leading questions. This Section discusses nine recent studies on children's suggestibility. The discussion concentrates on recent studies because they tend to be methodologically superior to earlier studies and because several liave been designed to address specifically the reliability of children as witnesses in child sexual abuse cases.

Suggestibility lias been defined as the extent to which individuals come to accept and subsequently imcorporate post-event information into their memory. ${ }^{163}$ The researcli that lias examined children's suggestibility tends to be divided into two separate areas of concern. One group examines factors that influence cognitive memory. These cognitive influences include strength of the trace (the duration of the child's exposure to the event), the length of the retention interval, the child's ambient stress level, and the possibility of destructive memory changing by postevent questioning. The other body of research examines social influences, including proclivity to conforn to the wishes of others, (especially powerful persons who control rewards and punishments), unwitting or unconscious effort to recall in a manner consistent witl stereotypes and beliefs, and whether children will lie when they have a motive to do so. ${ }^{164}$ Since the late 1960s there have been over seventy-five studies on the suggestibility of children. ${ }^{165}$

One major difficulty faced when interpreting the studies is that researchers have failed to reach a consensus on the key issue-some have concluded that children are impervious to suggestion; others have concluded that children have difficulty distinguishing reality from fantasy. ${ }^{166}$

162. Amici Curiae Brief of American Professional Society on the Abuse of Children et al. at 1516, Idaho v. Wright, 110 S. Ct. 3139 (1990) (No. 89-260).

163. Gisli H. Gudjonsson, The Relationship Between Interrogative Suggestibility and Acquiescence: Empirical Findings and Theoretical Implications, 7 PERSONALITY \& INDIVIDUAL DIFFERENCES 195 (1986).

164. See Steplien J. Ceci, The Suggestibility of the Child Witness: A Syntliesis Emphasizing the Most Recent Researcl 22 (rev. ed. 1990) [hereinafter Ceci, Suggestibility Synthesis] (unpublished manuscript). This Note does not discuss the effects of stress on children's memory.

165. Id. at 16 . During the 1980 s, approximately five times inore research was conducted on this topic than in all of the prior years of this century combined. Id. at 5,16 .

166. See, e.g., Gail S. Goodman et al., Child Sexual and Physical Abuse: Children's Testimony, in CHILDREN's EYewITNESS MEMORY, supra note 35, at 1; see also WAKEFIEID \& UNDERWAGER, supra note 26, at 85; D. Stephen Lindsay \& Marcia K. Johnson, Reality Monitoring and Suggestibility: Children's Ability to Discriminate Among Memories from Different Sources, in CHILDREN's EYEWITNESS MEMORY, supra note 35, at 92; Alvin A. Rosenfeld et al., Fantasy and Reality in Patients' Reports of Incest, $40 \mathrm{~J}$. CliniCAl Psychiatry 159, 161 (1979). 
Professor Stephen J. Ceci, a researcher in basic memory at Cornell University, suggests adopting a more centrist approach. He concludes from the research that children can he when the researcher provides a motive to he, that they can modify their stories to fit what the adult questioner believes to have happened, and that, in soine imstances, post-event suggestions can change a child's cognitive memory of an event. ${ }^{167}$ After examining the studies conducted on children's suggestibility, Ceci's approach appears to be the most defensible and free of advocacy-tainted research.

1. Can Children Be Motivated to Lie? In a study recently completed by Ceci, he found that children can he about abuse when they have a inotive to do so. In his two-phased experiment, lie tested the influence of five motivational factors: personal aggrandizement, protecting a loved one, avoiding embarrassment, sustaining a game, and conforming to a stereotype. ${ }^{168}$ Ceci found that even small material and psycloological rewards were extremely effective in motivating children to lie about previous events. For example, in one inamipulation, over fifty percent of the nursery school children hed about who had won a game in order to obtain a gumball. ${ }^{169}$ Certainly, none of the experimental mampulations was even remotely reminiscent of the powerful emotional and inaterial pressures that are often placed on children who testify in court proceedings about sexual assault. ${ }^{170}$ Thus, this study indicates that it is naive to assume that children cannot be motivated to produce false accounts of abuse.

One of the mamipulations in the Ceci study has particularly serious imphications for child abuse prosecutions. In the study, some of the children were kissed by their parents while being bathed the evening before being interviewed by the researchers. ${ }^{171}$ At the start of the interview, the children were told that it was "very nauglity" for an adult to kiss them

167. Ceci, supra note 164 , at $44-45$. Ceci also notes that researchers holding both extreme views tend to design studies that are advocacy packaged in the guise of science. Id. at 7 .

168. Id. at 37. The first phase of the study was an intensive case study of 10 three to four year old children. The second phase was conducted among a larger group of thrce to four year olds. After the adult experimenters spent 20 hours developing close relationships with each of the children, they brought the children in pairs to a laboratory that had the appearance of a playroom. The study was designed in two parts, a play period during which several manipulations were carried out, and two subsequent interrogations-one by a confederate playing the role of a nursery school teacher, and the other by the loved researcher. The interrogations were conducted individually for each child. Id. at 37-40.

169. The researchers ruled out simple memory failure as an explanation of the children's erroneous claims because it was clear from the control group's responses that the children knew exaetly who had won the games. Id. at 40 .

170. Id.

171. Id. at 39 . 
while they were naked. When asked if they had ever been kissed while naked, most of the children replied that they had not been kissed.172 On the one hand, this finding supports the idea that children are reluctant to reveal "abuse." It also indicates they can be motivated to he to protect loved ones (im this case, tlie parents wlio kissed them at batlitime). The study suggests, therefore, tliat we should examine whetler a child could be motivated to name someone outside the family when someone inside the family is perpetrating the abuse.

Other researchers have reported findings similar to Ceci's. When the studies are designed so that they provide motivational tilts toward lying, the children will often he. ${ }^{173}$ This researcli indicates that courts sliould consider whetlier the abuse mvestigator explored whether a child had a motive to fabricate an abuse allegation when evaluating the rehability of the expert's testimony.

2. Do Children Change Their Perception of an Event to Conform to Adult Perceptions? The imitial question of whether sexual abuse lias occurred is often a matter of low an adult interprets what a child says about an event, as opposed to what the child's factual memory of the event is. Because of the potential for adult influence on children's stories, researcliers liave examined whether children are susceptible to conforming their stories to fit an adult's perceptions. A study conducted by Clarke-Stewart focused on children's interpretations of events that could be construed as either sexually abusive or innocent. ${ }^{174}$ The researchers found that when the adult interviewers contradicted wliat actually liappened to the children, two-thirds of the children changed their stories to conform to the suggestions of the interviewer. ${ }^{175}$ Most of the reinaming

172. Id. at 41 .

173. See id. (referring to Douglas P. Peters, Confrontational Stress and Lying (paper presented at the biennial meeting of the American Psychology and Law Society, Williamsburg, Va., Mar. 16, 1990); Bussey, Children's Lies: A Developmental Analysis (paper presented at the same meetimg); see also Douglas P. Peters, Commentary: Response to Goodman, in SugGestibility of ChILDREN's Recollections, supra note 35, at 86, 90 (referring to the above unpublished studies and finding that children can be motivated to he when afraid of reprisal and to keep a secret).

174. Clarke-Stewart et al., supra note 35 , at 92 . In the study, 88 five and six year olds interacted individually with a confederate posing as a janitor. The confederate followed one of two scripts. In one, he cleaned toys, including a doll. In the other, he played roughly and suggestively with the doll. One hour later, another confederate interviewed the children. The imterview was either neutral and nonsuggestive, accusatory (suggesting the janitor was playing when he should have been working), or exculpatory (suggesting the janitor was working and not playing). In the latter two, the questions went froin mildly to strongly suggestive as the interview progressed. Following the first interview, each child was interrogated by a second interviewer, who either reinforced or contradicted the first mterview. Finally, the children were asked by their parents to recount what the janitor had done. Id. at 99-102.

175. Id. at 101 . 
children merged their account of the factual events with the interviewer's suggestions. ${ }^{176}$ At the end of the interrogation, only one child answered all the questions accurately. ${ }^{177}$ When the second interviewer contradicted the first interviewer, the children again changed their stories. ${ }^{178}$ The children's reports to their parents were consistent with the interviewers' suggestions. ${ }^{179}$ The researchers also found that the children who were the most suggestible shared several characteristics. They were more suggestible im many contexts, more likely to have parents who placed less value on self-direction, and inore likely to have parents who were less strict about lying than other parents. 180 Surprisingly, the inore suggestible children (those who most readily incorporated the interviewer's suggestions) had better verbal meinories than the children who did not go along with the interrogator's suggestions as quickly. ${ }^{181}$

Ceci has also tried to assess the degree to which children will try to conform their stories to their perceptions of an adnlt's wishes. ${ }^{182} \mathrm{He}$ found that children were more susceptible to modifying their story based upon an adnlt's post-event suggestion than based upon another child's suggestion. However, even the children who received their post-event suggestions from the older children were susceptible to suggestion. ${ }^{183}$ In another study, Ceci found that even when the child's original ineinory trace was retained, a majority of the children modified their stories to incorporate the adult's suggestions. ${ }^{184}$

Other researchers have found that children's definitions of what it means to lie can distort their testimony. Twenty-nine percent of a group of preschool children told a misleading story when interviewed by pohiceinen after their mothers told them to tell the misleading story. ${ }^{185}$ The researchers concluded that a child's understanding of what it means to

\footnotetext{
176. $I d$.

177. $I d$.

178. Id.

179. Id.

180. Id. at 102.

181. $I d$.

182. Ceci, Age Differences, supra note 35, at 79. In Ceci's study of 186 children, half werc given post-event erroneous information. Of those given the erroneous information, half received it from an adult and the other half received it from an older child. The three year olds who were not given erroneous suggestions recalled the event with $84 \%$ accuracy. The three year olds who received the biasing information from an adult recalled the event with $37 \%$ accuracy, and those who received the erroneous suggestions from an older child recalled the original event with $53 \%$ accuracy. Id. at 81-

183. Id. at 81-82.

184. Id. at 85 .

185. Ceci, supra note 164, at 25, (diseussing Jeffrey J. Haugaard et al, Children and the Truth, in Social AND Cognitive Factors in Deception Among ChILdREN (Stephen J. Ceci et al. eds., forthcoming 1992)).
} 82. 
lie is incompatible with the possibility that their loved ones would he. In other words, because children believe that their motliers are not liars, they believe their mother's version of the event must be the accurate one. ${ }^{186}$

Because this research indicates that children do modify their stories to fit adult perceptions, courts should pay particular attention to whether the abuse investigator liad a preconceived notion of wliat liappened to the child and then sought the child's confirmation. It also means that the investigator needs to have examined the family situation to see if the child is perhaps endorsing the preconceived ideas of a parent or otlier significant adult.

3. Are Children Resistant to Adult Suggestions? In opposition to the foregoing studies, some researchers have concluded that children are resistant to adult suggestions and difficult to mislead as to whether abuse has happened. Gail Goodman, a researcher at the State Umiversity of New York in Buffalo, is a leading proponent of the idea that children are impervious to adult suggestions when recounting abuse. One study she undertook witl Saywitz and other researchers was conducted at a medical center where the routine physical check-up included an examination for signs of sexual abuse. In the examination, a physician visually and physically inspected the exterior of the children's anuses and genitals. ${ }^{187}$ The children were asked sixty-eight questions, including ten misleading questions. ${ }^{188}$ In that study, three of the thirty-six (8.33\%) children gave incorrect responses to the abuse questions. ${ }^{189}$

Goodman feels that the leading questions are necessary in abuse investigations because the researchers found in this study that the children tended not to report the anal and gemital touching in free recall.190 At the same timie, slie acknowledges that the children's increased disclosure

186. Id.

187. Karen Saywitz et al., Children's Memories for Genital Examinations: Implications for Cases of Child Sexual Assault (unpublished manuscript); see also Goodman \& Clarke-Stewart, supra note 35 , at 98 . The researchers tested 72 middle- to upper-class, primarily white girls. Half of the children were five years old and the other half were seven years old. Half of the children of each age group underwent anal-genital exams and the other half did not. Saywitz, supra, at 3. Before the children were interviewed, the parents read through the questionnaires and struck out those questions they did not want asked of their children. Id.

188. Misleading questions included "How many times did the doctor kiss you?", "She didn't have any clothes on, did she?", and "The doctor didn't touch you, did she?" Saywitz et al., supra note 187 (Table 3).

189. Goodman \& Clarke-Stewart, supra note 35 , at 98.

190. See id. at 99. 
of gemital contact when asked specific questions comes at the expense of accuracy. 191

Before acceptimg Goodman's conclusion that specific questions arc necessary, however, it is important to recognize that the researchers themselves acknowledge that the study tilted the motivational factors toward telling the truth. ${ }^{192}$ As Ceci has noted:

Any of the motivational forces are capable of reversing many of the findings that will be reported. This concern is particularly applicable to those studies that have found children to be resistant to post-event suggestions, simce none of them to date have employed motivational manipulations that approach in intensity those found in the cases to which they wish to generalize. ${ }^{193}$

Essentially, the Saywitz and Goodman study addressed whether children are capable of recounting an event accurately-not whether children's accounts of abuse are valid. As Raskin and Yuille have poimted out, "[t]he distinction between accuracy and validity is crucial when there is the possibility of motives to report falsely or to fabricate an allegation." 194 In this case, the Saywitz and Goodman study did not address the principal question of whether children can he about abuse.

Furtheninore, some of the children's responses to the misleading questions would have led to suspicions of abuse if the researchers had not already known that the abuse had not occurred. For instance, one child reported that she had been touched on the vagina (when she had not becn) and two children claimed to have been touched on the buttocks (when they had not been). One child even elaborated and said that the doctor had tickled her buttocks with a long stick (when the child had not been touched on her buttocks at all). ${ }^{195}$

4. Can Post-Event Suggestion Change a Child's Cognitive Memory of an Event? Another danger of suggestive imterviews is that the postevent suggestions in those interviews may actually change children's cogintive memories of an event. This danger is increased with younger children-those who are six and younger. ${ }^{196}$ This possibility is disturbing because suggestive and leading questions are used extensively with young children because it is beheved they tend not to recount events fully when asked open-ended questions. ${ }^{197}$

191. See id.

192. Saywitz, supra note 187 , at 9.

193. Ceci, supra note 164 , at 26.

194. Raskin \& Yuille, supra note 26, at 184.

195. Saywitz, supra note 187 , at 8.

196. Ceci, supra note 164 , at $89-91$.

197. See, eg., Goodman et al., supra note 166, at 1. 
Theorists have hypothesized on how children's cognitive memories can be changed. Brainerd, Reyna, and Howe conceptualize memory traces as a loose bundle of integrated features. ${ }^{198}$ They hypothesize that over time and in response to erroneous suggestions, these features begin to loosen until they are nearly disintegrated. ${ }^{199}$ Their theory suggests that at least some of the susceptibility of younger children to post-event suggestion involves actual trace construction. Ceci accounts for individual and group differences in suggestibility in terms of the strength of the ineinory trace for the orignial event (the stronger the trace is, the harder it will be to distort it) and the strength of the trace of the erroneous suggestion (the stronger it is, the more likely it will lead to trace alteration or weakening). ${ }^{200}$ If this theory is correct, then no amount of subsequent questioning would undo the damage brought about by the erroneous information. ${ }^{201}$

Of course, this hypothesis has serious implications for any trial when a young child has been interviewed with suggestive and leading questions. Even if the child were to testify, no amount of cross-examination would disturb the child's credibility because the child would be testifying to what she beheves the truth to be. The McMartin Preschool trial in 1986-1990 may possibly be an excellent illustration of this theory at work. ${ }^{202}$ In that ease, the jurors thouglit the children were credible witnesses when recounting the abuse but ultimately voted not guilty because of the suggestivity and coerciveness of the interviews. ${ }^{203}$ One juror explained: "If we had not seen those tapes [of the children being interviewed], I would have been able to beheve their testimony a little more." ${ }^{204}$ It is possible that the children were credible witnesses because they were not consciously lying. ${ }^{205}$

198. Ceci, supra note 164, at 22; see also Brainerd \& Ornstein, supra note 69 at 10,17 (hypothesizing that meinory storage failure is a inatter of inemory trace fading); Elizabeth Loftus et al., Creating New Memories That Are Quickly Accessed and Confidently Held, 17 MEMORY \& CoGNITION 607-16 (1989) (stating that misleading post-event information coinpetes with original information in such a manner that it alters the underlying memory so that the original memory is "erased" through a destructive updating process).

199. Ceci, supra note 164 , at 22 .

200. See id. at 24.

201. See id. at 23.

202. Many articles have been published about the McMartin case. See, e.g., Robert Safian, McMartin Madness: Ten Days in the Life of the Longest, Most Gruesomely Difficult Criminal Trial Ever, AM. LAw., Oct. 1989, at 46.

203. For a partial transcript of one of the interviews see infra note 208.

204. Besharov, supra note 18 , at 44.

205. This also means that if those tapes had not been made available to the defense and if they had not been adinitted at trial, the defendants might have been wrongly convicted. 
5. Does the Research Reflect How Children Behave in the Real World? One problem that none of the studies will ever be able to completely overcome is the one of ecological validity. Briefly, ecological vahidity refers to the generalizability of a study from the research context to the infinitely more complex real world. A legitimate concern is that children's behavior in a research study may have little resemblance to their behavior in reality. Children in the real world are faced with vastly greater complexities than the simple variables created in research laboratories.

The central problem is that it would be unethical and highly abusive to design a test that is fully ecologically valid. Such a test would call for subjecting known, unabused children to the same sort of mvestigative interview that a suspected abused child submits to. The reason that little motivational research has been conducted is that it is difficult to do such research in an ethically acceptable manner. The children would have to be subjected to degrading and embarrassing mampulations. ${ }^{206}$

\section{At What Age Do Children Achieve Adult Levels of Resistance to} Suggestion? There is some disagreement among researchers about the exact age at which children achieve adult levels of resistance to suggestion. Ceci has found that it occurs around ages seven to nine.207 An miportant caveat to remember about this research is that no child in a research situation has ever been subjected to the great pressure to conform her story to an adult's notion of what happened as actually occurs in the real world. ${ }^{208}$ Therefore, to assume that a child over the age of seven is resistant to suggestion may be erroneous.

206. See Ceci, supra note 164, at 26.

207. See id. at 82.

208. See WAKEFIELD \& UNDERWAGER, supra note 26, at $45-47$ (describing an interview with an eight-year old boy conducted by Kee MacFarlane in the McMartin Preschool investigations):

She tells him that a lot of other kids have told about the secrets, that the ones who tell are "a big help in figuring things out," and that soine of the teachers did "yukky" things. He asks which teachers and MacFarlane tells him that the puppets know and they can tell "the secret inachine" (the microphone). The child does not know any secrets and doesn't produce anything that pleases MacFarlane. The puppet on MacFarlane's hand asks, "Are you dumb or smart?" The puppet on the lad's hand responds, "I'in sinart." MacFarlane tells him "we're talking to the older kids because they're smartest. They can help. We can figure out these games if you're smart." The lad again says, "I'n sinart." MacFarlane tells him, "It was a long time ago. You might not remenber .... We can pretend." The boy says, "I can remember," but only talks about puppets beating each other up. MacFarlane says, "Bird says some of them are naked games." He asks why they played naked games and MacFarlane says, "It was a special school where they play naked games. Remember?" MacFarlane then tells the boy that the inommies and daddies had a special meeting and they know about the secrets but that this child"s parents said "We don't know if (name) has a good enough memory." The boy immediately says, "I have a good enough memory." MacFarlane says "Oh great! .. . Let's figure out a naked game ... Later we can tell the mommies and daddies. Oh, they will be so happy." The boy begins to talk about games he supposedly remembers but none of the teachers are described as naked. The following exchange occurs: 
Because the research indicates the rehiability of children's accounts of abuse is undermined by suggestive interviewing techniques, courts should be vigilant when evaluating interviews for indications of undue suggestivity. Courts should not be misled by assertions that the use of leading questions with children does not necessarily render responses untrustworthy, ${ }^{209}$ as this only conceals the real issue. Obviously, a child can accurately respond to a leading question just as a person who has been beaten can inake an accurate confession. But in both cases, the technique used in eliciting the stateinents also creates the potential for inaccurate, unrehiable, and untrustworthy responses.

\section{Problems Created by Inadequate Assessments, Interviewer Bias, and Other Suggestive Interviewing Techniques}

Because the research shows that a significant percentage of children are responsive to adult prcconceived idcas of what has happened to the children, it is crucial to be aware of the common pitfalls of investigative interviews and to recognize that interviewers often give children cues as to what they expect the children to relate through ineans other than leading questions. A inajor goal for investigators should be to insure that a child's information does not becoine distorted or falsified by confounding influences. ${ }^{210}$ Furthermore, "[i]t nust be acknowledged that all interviews will be influenced to soine extent by interviewer behaviors. All investigatory interviewers inust be vigilant during the interviewing process to minimize the impact of behavioral factors."211

Factors of the interview itself that can falsify and confound a child's report include the lack of investigatory independence, pursuit of an

\footnotetext{
MacFarlane: I thought that was a naked game.

Child: Not exactly.

MacFarlane: Did somebody take their clothes off?

Child: When I was there no one was naked.

MacFarlane: We want to make sure you're not scared to tell.

Child: I'm not scared.

MacFarlane: Some of the kids were told they might be killed. It was a trick. All right,

Mr. Alligator, are you going to be stupid, or are you smart and can tell. Some think you're smart.

Child: I'll be smart.

MacFarlane: Mr. Monkey (puppet child had used earlier) is chicken. He can't remember the naked games, but you know the naked movie star game, or is your memory too bad?

Child: I haven't seen the naked movie star game.

MacFarlane: You must be dumb!

Child: I don't remember.

209. See, e.g., Amici Curiae Brief of American Professional Society on the Abuse of Children et al. at 21, Idaho v. Wright, 110 S. Ct. 3139 (1990) (No. 89-260).

210. See Kathleen M. Quinn et al., Influences of an Interviewer's Behaviors in Child Sexual Abuse Investigations, 17 BULl. AM. ACAD. PSYChIATRY \& L. 45, 45 (1989).

211. Id. at 52 (footnote omitted).
}

Id. at $45-47$. 
agenda, leading, and coercion. ${ }^{212}$ Investigatory independence requires the interviewer to adopt an "objective stance of not allying him/herself with any particular individual involved in the investigation of the allegation."213 The interviewer should also maintain independence by not giving the child verbal and behavioral cues that can contammate the interview. An exainple of the latter would be stroking the child's head as a reinforcement for an answer that confirms the interviewer's assumptions about the allegation. ${ }^{214}$

Many investigators are unaware of their own behaviors that can affect the outcome of an interview. For example, Myers denies that interviewers can shape a child's responses in his amicus brief for Idaho $v$. Wright:

At one point, the psychologist [testifying for the defendant at trial] contended that children's responses can be easily "shaped." The psychologist went on to state that "one of my colleagues in the Portland area, Bill McGeiver [sic] has found that simply by nodding the head and saying 'um-hum' he can shape, so to speak, gradually shape behaviors in young children that border on the sexually bizarre." ... It is clear that the McGeiver [sic] findings are not to be found in the scientific hiterature. Amici know of no scientific studies indicating that children or adults can be "shaped" by nodding of the head and saying "um-hum" to make false claims of sexual abuse..215

Such a stateinent shows a gross lack of knowledge of the scientific literature. The fact that the imterviewer can give behavioral cues that can affect the outcoine of an interaction is well understood in the scientific literature. ${ }^{216}$ It is precisely why, for exainple, when testing pharmaceuticals, the drugs and placebos are administered with a double-blind. That is, not only does the research subject not know whether she is getting a placebo or the real thing, but also the researcher giving the drugs does not know who is getting the placebo and who is getting the drug.

Pursuit of an agenda can also contaminate the information given by a child during an investigatory interview. All interviewers tend to approach an investigation with soine assumptions about the veracity of the

212. Sue White \& Kathleen M. Quinn, Investigatory Independence in Child Sexual Abuse Evaluations: Conceptual Considerations, 16 Bull. AM. ACAD. Psychiatry \& L. 269, (1988).

213. Kathleen Quinn et al., Child Evaluator's Roles in Child Sexual Abuse Assessments, in SEXual Abuse Allegations in Custody and Visitation Cases 94, 94 (E. Bruce Nicholson \& Josephine Bulkley eds., 1988).

214. White \& Quinn, supra note 212, at 270.

215. Amici Curiae Brief of American Professional Society on the Abuse of Children et al. at 21, Idaho v. Wright, 110 S. Ct. 3139 (1990) (No. 89-260).

216. See, e.g., 1 ZISKIN, supra note 154, at 163-67 (sumınarizing studies that show that exaniner expectations infiuence outcomes). 
allegations.217 The degree to which an agenda is pursued, however, can greatly affeet the information given. Quinn has said:

The most counterproductive interviewing occurs when the interviewer has a strong preconceived notion of what occurred that he or she seeks to have the child endorse. . . . The pursuit of an agenda is a major reason for faulty investigations that may result in false positive or false negative assessment of a complaint." 218

Too often, interviewers pursue an agenda by asking a large number of leading or suggestive questions, asking questions that require only a yes or no answer, asking multiple choice questions, or asking questions that disconfirm what the child has just said.219 An example of the last type occurs in the following scenario: An interviewer asks the child, "Who touched your bottom?" When the child responds "My mommy" the imterviewer assumes the touching was during hygienic care and does not investigate. She instead follows up with, "Yes, but who else touched your bottom?" When the child says, "My daddy," the interviewer is agam displeased with the child's response and says, "Right, but didn't Uncle Joe touch your bottom?"220 Only the child's assertiveness in correcting this assumption will overcone this interviewer's agenda. ${ }^{221}$

The phrasing of questions in an interview will have great impact on the rehability of the child's responses. For instance, in the Jordan, Minnesota sexual abuse scandal, a child witness confessed that he had made up detailed stories of abuse because " 'I conld tell what they wanted me to say by the way they asked the questions." "222

Coercion is another common techirique used in imvestigative interviews. It nicludes threats that the child will not be able to see her parents or return hoine until she tells "what happened", that she can not go to the bathroom until she tells, or by asking repetitive questions. The repetitive questioning commumicates to the child that she has been giving imcorrect or inadequate answers. ${ }^{223}$

Other influences that may alter the child's statenients imclude factors outside the interview. These include commumications between parents and children, media coverage, formal educational experiences regarding child safety and abuse prevention, and other discussions that

217. This is not to suggest in any way that this is wrong. It is probably not humanly possible to leave all biases at the doorstep.

218. Kathleen M. Quinn, The Credibility of Children's Allegations of Sexual Abuse, 6 BEHAV. SCI. \& L. 181, 185 (1988).

219. White \& Quinn, supra note 212, at 271-74.

220. Id. at 273.

221. Id. at 274.

222. Aric Press et al., The Youngest Witnesses, Newsweek, Feb. 18, 1985, at 72, 75.

223. White \& Quinn, supra note 212, at 275. 
concern the abuse in the presence of the child. The investigator must evaluate this contamination's impact on how the disclosure was made and the content of the allegations. 224

\section{The Incidence Rate of False Accusations}

Responsible experts on both sides of the sex abuse controversy acknowledge that false accusations exist, but they differ sharply on the extent of the problem. Dr. Maria Sauzier, a child psychiatrist who beheves that child sexual abuse is not overdiagnosed but rather is underdiagnosed, has said that "[t]lie belief that "children never lie about sexual abuse' [is] fostered and supported by overzealous and misguided professionals."225 Predictably, child advocates tend to support a low base-rate for the incidence of false accusations and those on the opposite side tend to endorse a higher incidence rate of false allegations. ${ }^{226}$ An evaluator's perception of the base-rate of false allegations affects the accuracy of that evaluator's appraisal of whetlier a particular child has been abused.227 There is no way of knowing what the real incidence rate of false accusations is in the population, but those who believe that false accusations occur less frequently than they actually do will make false-positive diagnoses (tliey will diagnose children as abused when they have not been abused). Conversely, those who believe that the incidence rate is ligher than it actually is will make false-negative diagnoses (they will diaguose children as nonabused when they liave been abused). However, because we do not know the actual occurrence rate of false allegations, we also cannot conclusively know whether an expert endorses a too-low or toohigh base-rate of false accusations. We do know that experts who believe that "children never he" are outside the boundaries of what is reasonable because every researcher who has atteinpted to assess the incidence-rate

224. See Quinn, supra note 210 , at 46.

225. Quinn et al., supra note 5, at 794.

226. For example, Rebecca Friend, program coordinator for the Pro Child and Family House in Charlotte, North Carolina, said in a phone interview that she thinks that there are not many, if any, false allegations, and that false allegations would only come from older children. She said that their facility has never encountered a situation where the allegation was false. Telephone Interview with Rebecca Friend (Sept. 6, 1990). Lucy Berliner, director of a sexual assault center in Seattle, Washington, has said: "No competent professional disputes the fact that some small proportion of sexual abuse reports are fictitious." Quinn et al., supra note 5, at 793. Berliner's view in 1989 that some reports are fictitious differs from statements that she has previously inade. In 1981, she said that "there is no evidence to support the idea that children falsely report sexual abuse." Jon R. Conte \& Lucy Berliner, Sexual Abuse of Children: Implications for Practice, 62 SocIal CasewORK: J. CoNTEMP. SOC. WORK 601 (1981).

227. See, e.g., 1 ZISKIN, supra note 154, at 83-95. This is just a restatement of a basic precept of validity analysis of social science research. This idea can be demonstrated with a simple example: If the true rate of false allegations is $10 \%$ and the investigator believes that the rate of false allegations is zero percent, then $10 \%$ of the children assessed as abused would actually not be abused. 
of false allegations has discovered that false allegations exist.228 Therefore, courts that allow the testimony of experts who behieve that children never lie are necessarily admitting false testimony against innocent defendants more often than courts that do not allow such unrehiable testimony. Courts should not qualify these people as experts. Therefore, abuse investigators, as well as the courts, should consider if the allegation is false. The American Acadeiny of Child and Adolescent Psychiatry, in its guidelines for the clinical evaluation of child and adolescent sexual abuse, recommends considering whether or not an allegation is false. 229 In order to determine the credibility of an account, it is essential that the child be evaluated in the context of the family and her development to determine what factors might be influencing the parents' or child's allegations. Evaluators inust attempt to understand the present family dynamics, the child's relationship with her parents, and the parents' relationships with one another and with significant others. Equally important is the child's past history of trauma, especially sexual abuse, the child's level of coguitive and einotional development, and the child's credibility. ${ }^{230}$

It is particularly difficult to detect when a previously abused child names the wrong person. These cases are complicated by the fact that because of the previous abuse, the child is able to give detailed descriptions of sexual activities. In the Jones and McGraw study of the incidence-rate of false allegations, the researchers found that four of the false allegations made by children in their sample were made by girls who had been previously sexually abused. ${ }^{231}$

228. Despite this, experts have testified that "children never lie." See, e.g., State v. Raye, 326 S.E.2d 333, 335 (N.C. Ct. App. 1985) (holding that pediatrician with 15 years of experience had qualifications superior to jury's for determining whether child would fantasize sexual abuse); see also State v. D.R., 537 A.2d 667, 673 (N.J. 1988) ("The overwlielming opinion of mental liealth workers, social welfare workers, and police investigators is that children almost never make false [sexual abuse] reports."); State v. Rogers, No. 90 CRS8256 and No. 90 CRS8257 (N.C. Super. Ct. Apr. 26, 1991) (recording testimony of child abuse investigator that "children do not fantasize about sexual abuse").

229. Guidelines for the Clinical Evaluation for Child and Adolescent Sexual Abuse, Position Statement of the American Academy of Child and Adolescent Psychiatry, 27 J. AM. ACAD. CHILD \& ADOLESCENT Psychiatry 655 (1988):

The possibility of false allegations needs to be considered, particularly if allegations are coming from the parent rather than the child, if parents are engaged in a dispute over eustody or visitation, and/or if the child is a preschooler.

... False allegations may arise in otler situations as well, such as the inisinterpretation of a clild's statement or beliavior by relatives or caretakers. . . . Cliildren who have experienced prior sexual abuse may sometimes inisinterpret actions of adults or accuse the wrong person of abuse.

Id. at 655-56.

230. Benedek \& Sclietky, supra note 27, at 916.

231. Jones \& McGraw, supra note 36 , at 31. 
Numerous studies have tried to determine the actual incidence-rate of false allegations. ${ }^{232}$ One early study looked at children from intact families in which abuse by the father was alleged. In that study, three out of forty-six $(6.52 \%)$ children made false allegations of sexual abuse. ${ }^{233}$ Other studies that did not distinguish incest cases from other situations where sexual abuse was alleged found the rate of false accusations to range from three percent to about eight percent. In one sample of 181 children, the researchers found after extensive evaluation that eight percent were false reports. ${ }^{234}$ In another study, Jones and McGraw undertook a comprehensive review of 576 reports inade to the Denver Department of Social Services. They also found that eight percent were fictitious. ${ }^{235}$ Faller described a sample of 148 cases where sexual victimization was alleged and found that three percent were untrue. ${ }^{236}$

Other studies that have looked at the rate of false accusations in visitation and custody disputes have found shockingly high rates of false allegations. In one sample, Benedek and Schetky found ten out of eighteen (fifty-five percent) to be false. ${ }^{237}$ Green documented four out of eleven (thirty-six percent) as being false. ${ }^{238}$ Brant and Sink found three of four (seventy-five percent) to be false. ${ }^{239}$

232. The studies used different methods for determining false allegations. Some of the studies did not reveal their methods in making the determination. None of the studies based their determination that an allegation was false on the legal outcomes of the cases. See, e.g., id. The Jones and McGraw study identified several factors it considered in determining whether an allegation was true or false. Those factors included unique or distinguishing details in the sexual encounter and/or the surrounding circunstances, the consistency of the child's words and sentence formation with the child's developmental status, whether the account was from the child's perspective, whether and how the child expressed emotion, the child's psychologieal response, and elenents of secrecy, coercion, and threats in the child's account. The researchers also considered family psychological history and the behavior of the child during the period that the abuse allegedly occurred. Id. at 32-34.

233. Jean Goodwin et al., Incest Hoax: False Accusations, False Denials, 6 Bull. AM. ACAD. Psychiatry \& L. 269, 270 (1978).

234. Horowitz et al., False Accusations of Child Sexual Abuse (unpublished manuscript 1985), referred to in Mark D. Everson \& Barbara W. Boat, False Allegations of Sexual Abuse by Children and Adolescents, 28 J. AM. ACAD. Child \& Adolescent Psychiatry 230, 231 (1989).

235. Jones \& McGraw, supra note 36 , at 31.

236. Katherine C. Faller, Child Sexual abuse: AN INTerdisciplinary Manual for Diagnosis, Case Management, AND TReatment 22, 126 (1988).

237. Elissa P. Benedek \& Diane H. Schetky, Allegations of Sexual Abuse in Child Custody and Visitation Disputes, in Emerging Issues in ChIld Psychiatry and the LaW 145, 155 (Diane H. Schetky \& Elissa P. Benedek eds., 1985).

238. Arthur H. Green, True and False Allegations of Sexual Abuse in Child Custody Disputes, 25 J. AM. ACAd. Child Psychiatry 449, 449 (1986).

239. René Brant \& Frances Sink, Dilemmas in Court-Ordered Evaluation of Sexual Abuse Charges During Custody and Visitation Proceedings, (paper presented at the 31st Annual Meeting of the American Acadeiny of Child Psychiatry, Toronto, Can., Oct. 12, 1984), referred to in Green, supra note 238 , at 449 . 
None of the studies can be said to represent fairly the true rate of false accusations. Some are plagued by extremely low sample sizes so that it is difficult to generalize from these studies to the overall rate for untrue allegations. Additionally, it is not accurate to generalize from a study looking at incest in intact families to situations in which the abuse has been alleged against a neighbor, adult friend, or daycare provider. Furthermore, it is difficult to determine if the studies themselves accurately classified the children as abused or nonabused. 240

Nonetheless, the studies do illustrate that abuse imvestigators need to evaluate seriously the veracity of an allegation to perform a valid imvestigation. They also show the need to understand exactly how an abuse allegation originated. Courts can use the studies to determine just where an investigator's bias is by asking what the investigator beheves the rate of false allegations to be. Courts should give heightened scrutimy to testimony by any interviewer of the child who behieves the rate of false allegations to be five percent ${ }^{241}$ or less to see that she has fully explored the possibility of a false allegation. If the investigator has not fully explored that possibility, the information gathered in the interview should not be admitted at trial.

\section{GUIDELINES FOR COURTS WhEN ADMITTING EXPERT Testimony Based on ChIld SeXual ABuse INVESTIGATIVE INTERVIEWS}

The studies surveyed in Part III reveal that investigative techniques in child sexual abuse cases are unrehable. They illustrate the need for courts to proceed with caution before admitting expert opmion testimony in child sexual abuse proseeutions. Anatomical doll studies should warn courts not to admit testinony based on abuse interviews in which the dolls were used. The children's suggestibility studies should make courts vigilant for sigus of suggestiveness in the imvestigative interviews. The studies on the imcidence rate of false allegations should motivate courts to question whether the investigative interviewer thoroughly exannined

240. See, eg., Robyn M. Dawes et al., Clinical Versus Actuarial Judgment, 243 ScIENCE 1668 (1989) (discussing the pitfalls of clinical judgments); see also LEE COLEMAN, THE REIGN OF ERROR: PsychIATRY, AUTHORITY, AND LAW (1984); 1 ZISKIN, supra note 154.

241. Five percent is admittedly a somewhat random figure. It was chosen because an expert who endorses the notion that "children do not lie" or that they "almost never lie" probably has not perceived a need to investigate the possibility that the allegation is false and may be less aware of how her interactions with the child may affect the child's account of abuse. For instance, many child protection team manuals exhort the investigators to "presume that the child is telling the truth." See, e.g., Mary Wells, Guidelines for Investigative Interviewing of Child Victims of Sexual Abuse, in SeXual Abuse of Children in the 1980s 53 (1986). 
the possibility that the child had a motive for producing a false allegation. In short, the research studies illustrate that courts should adhere to conventional evidentiary analysis when admitting hearsay and expert opinion testiniony im child sexual abuse prosecutions. ${ }^{242}$

Part IV provides courts with some concrete guidelines that will aid them in assessing investigative interviews. There are good reasons for courts to provide a screening function for evidence im child sexual abuse cases. Rather than allowing a "battle of the experts," courts should inake preliminary findings about the rehability of the evidence because of the harm to innocent defendants and because the judicial process is potentially harmful to children who have not in fact been abused. ${ }^{243}$ Courts should also consider the damaging effect to a child who has actually been abused but where there has been an mept investigation.

A further reason why courts should provide a screening function is that heightened judicial scrutiny will pressure investigators to inprove their techniques. Prosecution experts are intmiately tied to the decision to prosecute. The Pro Child House in Charlotte, for example, has weekly meetmgs with the prosecutor's office. ${ }^{244}$ This interdisciplinary model of cooperation is practiced in a growing number of communities in the Umited States. ${ }^{245}$ If the court systematically screens out improperly conducted imvestigations, it will have a beneficial impact on how children are interviewed by these imvestigative agencies. One reason that abuse allegations are so superficially investigated is that agencies are chronically underfunded and overwhelined with cases. However, sloppy investigations have the effect of externalizimg the agencies' costs by overburdening the courts, the prosecutors' offices, the pemitentiaries, and the defendants; they also do great harm to the children involved.

242. See supra Part II (discussing the legal doctrines implicated when courts consider the adinissibility of child sexual abuse investigative interviews).

243. See Moisy Sliopper, Letter to the Editor, 28 J. AM. ACAD. CHILD \& ADOLESCENT PSYCHIATRY 799 (1989). Shopper, a psycliologist who testified for the defense in a case, commented:

I would suggest that the children were traumatized by repeated interviews witl different interviewers all eager to prosecute and collect allegations but untrained and unaware of their overzealous and coercive attitudes. ...

To treat false allegatious as actuality is not a harmless error, altliough we have yet to fully research and document the extent of that harm. When there are false allegations the very investigative and prosecutory process, well intentioned but zealously pursued, needs to be recognized as being potentially as harmful as actual sexual abuse. Both are overstimulating, botll serve to sexualize relationships, both interfere with and distort the child's relationship with adults, and both undermine the child's developing ego abilities. Id.

244. Telephone Interview with Rebecca Friend, supra note 226.

245. Id.; see also Bulkley, supra note 19, at 210; Robert E. Cramer, The District Attorney as a Mobilizer in a Community Approach to Child Sexual Abuse, 40 U. MiAmI L. REV. 209 (1985). 
The social science research demonstrates that courts should expand the Wright Court's hist of pertinent factors ${ }^{246}$ when determining whether to admit expert testimony based on a child sexual abuse mvestigative interview. This Note suggests five additional indicia of reliability for courts to consider.

First, testimony based on imvestigative interviews in which anatomically detailed dolls were used should not be admitted into evidence. Proponents of doll-based interviews have not carried their burden of proof in deinonstratimg that the dolls are reasonably relied upon as indicators of abuse. ${ }^{247}$ The doll studies deinonstrate that significant percentages of nonabused children interact sexually with anatomically detailed dolls. If the court decides not to exclude categorically assessments obtained with the use of the dolls, it sliould still do so in cases where it was the only assessment tool used. Over-retiance on any one tool is not valid. In addition, courts should be particularly vigilant for other signs of suggestiveness when evaluating an interview wliere dolls were used.

Second, the court should determine whether the interview(s) were unduly suggestive and leading, as the questions asked may undermine the rehiability of the answers received. There is a need for courts to scrutinize child sexual abuse imvestigations because the research on children's suggestibility has shown that children are suggestible and because child advocates and child protection manuals have advocated using suggestive and leading interviewing techniques. ${ }^{248}$ Although social science researchers on children's suggestibility have reached varying conclusionsfroin finding thiat most children are resistant to suggestion ${ }^{249}$ to finding that children tend to weave fantasy into reality ${ }^{250}$ - the mainstream of the research has found that children can be inotivated to $\mathrm{he}^{251}$ and that they will modify their stories to fit an adult's perception. ${ }^{252}$ Particularly if the child's first statement about abuse occurred while being interviewed by an abuse evaluator, then a suggestive interview severely undermines any confidence that the abuse allegation is legitimate. Courts should examine not ouly the actual content of the investigator's questions, but also evaluate the investigator's behavioral factors that could have influenced

246. Idaho v. Wright, $110 \mathrm{~S}$. Ct. 3139, 3150 (1990) (listing spontaneity and consistent repetition, mental state of the declarant, use of terminology unexpected of a child of similar age, and lack of motive to fabricate, but excluding physical evidence of abuse, as factors to consider in admitting hearsay). See supra note 70 and accompanying text.

247. See supra Part III(A).

248. See supra notes 161-205 and accoinpanying text.

249. See Saywitz, supra note 181, at 5-6.

250. See WAKEField \& UNDERWAGER, supra note 26 , at 85.

251. See Ceci, supra note 164 , at 22 .

252. See supra Part $\operatorname{III}(B)(2)$. 
or coerced the child to make an abuse allegation. Courts need to consider whether the investigator appeared to be pursuing an agenda or whether there were other indications of interviewer bias. 253

Third, the court should check whether a full psychological history was obtained from the child both before and after the alleged abuse and whether developmental tests were administered. Understandimg a child's behavioral characteristics exhibited before the abuse allegation was made gives the investigator a better understanding of the child's current behavior. Such an imvestigation can help to determine whether the child had been previously abused ${ }^{254}$ or if there are other factors in the child's life that can account for a child's symptoin formation, such as a divorce or custody dispute or other life disrupting events. ${ }^{255}$ The developmental tests provide a certain amount of objective information about the child, thus enhancing a clinician's ability to understand a child's behavior. Such objective tests can also help guard against a clinician's pursuit of an agenda and to weed out probleins created by the interviewer's biases. ${ }^{256}$

Fourth, the court should ask whether the investigator has looked at the underlying family dynamics. Requiring investigators to evaluate the family dynamics and to do full psychological and developmental evaluations of the children will lessen the chance that notives to fabricate will go undiscovered or that adult misperceptions are at the root of the child's abuse allegation. ${ }^{257}$ The abuse investigator needs to have examined as fully as possible how the child's abuse allegation originated and to what sort of questioning the child has already been subjected before the evaluator's interview to ensure that other sources have not contaminated the child's abuse allegation. 258

Finally, the court should consider whether the investigator has adequately considered the possibility of a false allegation. This last factor reflects on the probable accuracy of the investigator's diaguosis. ${ }^{259}$

Sometimes, the abuse investigators do not adequately docuinent their investigations and the court is thus unable to determine the adequacy of an investigation. However, that lack of documentation in itself

253. See supra notes $210-24$ and accompanying text.

254. Previously abused children are one group who have been identified as being susceptible to false allegations. See, e.g., Jones \& McGraw, supra note 36 , at 31.

255. See supra notes 237-39 and accompanying text.

256. See supra notes $218-23$ and accompanying text.

257. See supra notes $175-86$ and accompanying text.

258. See supra note 224 and accompanying text.

259. See supra notes 227-29 and accompanying text. 
suggests that the investigation was inadequate. The best sort of documentation would be videotapes, ${ }^{260}$ so that a court could see fully just how a child's story was ehicited-whether there were verbal and behavioral suggestions, whether the child was subjected to repetitive and coercive questioning, and whether the child gave her own account or merely agreed to some of the interviewer's suggestions.

\section{CONCLUSION}

Courts need to recognize that even when investigations are thorough and professional, a certain percentage will be false-positives and a certain percentage will be false-negatives. Human psychology is coinplex and our abilities to know what has happened to a given child are limited. However, we do have the capabilities and knowledge to investigate abuse allegations with much more sophistication than is currently done by the majority of child protection teams. We owe it to children and to innocent defendants to apply what we know.

We need to stop approaching the problem of child sexual abuse einotionally. It is proper to acknowledge that child abuse is repugnant and repulsive. However, because it is an issue where it is so difficult to separate out our inoral revulsion when evaluating whether an allegation is true or false, it can be difficult to sift through the evidence and arrive at a just result. This Note is written with the hope of being one step toward achieving more just results.

260. Suggesting that the interviews be videotaped does not mean that these taped interviews should be admissible at trial. 
